\title{
Emergent Aquatics: Stand Establishment, Management, and Species Screening A Subcontract Report
}

\author{
D. C. Pratt \\ N. J. Andrews \\ D. R. Dubbe \\ E. G. Garver \\ M. Penko \\ P. E. Read \\ E. S. Zimmerman \\ University of Minnesota \\ Bio-Energy Coordinating Office
}

November 1982

Prepared Under Subcontract No. XK-1-1087-1

SERI Technical Monitor: Paul Bergeron

Solar Energy Research Institute

A Division of Midwest Research institute

1617 Cole Boulevard

Golden, Colorado 80401

Prepared for the

U.S. Department of Energy

Contract No. EG-77-C-01-4042 


\author{
Printed in the United States of America \\ Available from: \\ National Technical Information Service \\ U.S. Department of Commerce \\ 5285 Port Royal Road \\ Springfield, VA 22161 \\ Price: \\ Microfiche $\$ 3.00$ \\ Printed Copy $\$ 5.25$
}

\begin{abstract}
NOTICE
This report was prepared as an account of work sponsored by the United States Government. Neither the United States nor the United States Department of Energy, nor any of their employees, nor any of their contractors, subcontractors, or their employees, makes any warranty, express or implied, or assumes any legal liability or responsibility for the accuracy, completeness or usefulness of any information, apparatus, product or process disclosed, or represents that its use would not infringe privately owned rights.
\end{abstract}




\section{TABLE OF CONTENTS}

$\underline{\text { Page }}$

1.0 General Introduction..................................................................... 1

2.0 Typha Stand Establishment and Management...................................... 5

$2.1 \quad$ Introduction.......................................................................... 5

2.2 Planting Material and Methods...................................................... 5

2.2.1 Objective........................................................................ 5

2.2.2 Methods............................................................... 6

2.2.2.1 Seed................................................................... 6

2.2.2.2 Seedling........................................................ 6

2.2.2.3 Rhizome...................................................... 6

2.2.3 Results and Discussion................................................... 8

2.2.3.1 Seed........................................................ 8

2.2.3.2 Seedling vs. Rhizome Planting Material

2.2.3.3 Comparison...................................................... 9

2.2.4 Conclusions................................................................... 15

2.3 Land Preparation.......................................................................... 15

2.3.1 Objectives..................................................................... 15

2.3.2 Methods......................................................................... 15

2.3.3 Results and Discussion................................................... 15

2.3.3.1 Soil Nutrient Profile........................................ 15

2.3.3.2 Management Considerations.............................. 17

2.3.4 Conclusions........................................................... 20

3.0 Typha spp. Nutrient Experiments..................................................... 21

3.1 Introduction....................................................................... 21

3.2 Effect of Nitrogen, Phosphorus, and Potassium on First

Season Yield................................................................................ 22

3.2.1 Objectives.............................................................. 22

3.2.2 Methods...................................................................... 22

3.2.3 Results and Discussion................................................ 22

3.2.4 Conclusions................................................................ 28

3.3 Nutrient and Yield Comparisons................................................. 31

3.3.1 Objectives.......................................................................... 31

3.3.2 Methods....................................................................... 31

3.3.3 Results and Discussion............................................. 31

3.3.4 Conclusions.................................................................... 33 
TABLE OF CONTENTS (continued)

$\underline{\text { Page }}$

4.0 Wetland Species Comparisons and Micropropagation................................. 37

4.1 Introduction................................................................................... 37

4.2 Wetland Species and Typha Genotype Comparisons......................... 38

4.2.1 Objectives...................................................................... 38

4.2.2 Methods............................................................................ 38

4.2.3 Results and Discussion..................................................... 38

4.2.3.1 Wetland Species Comparison........................... 38

4.2 .3.2 Typha Genotype Comparison........................... 40

4.2 .4 Conchusions...................................................................... 47

4.3 Micropropagation of Typha Spp................................................... 47

4.3.1 Objectives.......................................................................... 47

4.3.2 Methods and Results...................................................... 47

4.3.2.1 Establishment of Typhe Explants in

4.3.2.2 Regeneration of Plantlets.................................... 50

4.3.2.3 Establishment of Tissue-Cultured Plantlets

in Conventional Medium in Field Conditions... 51

4.3.3 Conclusions.................................................................. 51

5.0 Future Research........................................................................... 53

References.................................................................................................... 55

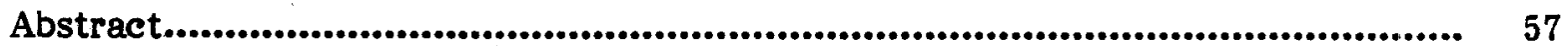


LIST OF FIGURES

Page

1-1 Available Wetlands for Bioenergy Purposes: Land Use and Drainage Constraints............................................................................ 2

2-1 Excavation Scheme - Zim, Minnesota.......................................... 7

2-2 First Year Typha Yields as Affected by Land Preparation and Planting Material........................................................................... 11

2-3 First Year Typha Shoot Density as Affected by Land Preparation and Planting Material............................................................................. 12

3-1 Factors Affecting First Season Yields.............................................. 26

3-2 Nutrient Standing Crop at the End of the First Growing Season........... 29

3-3 Available Soil Phosphorus and Potassium Levels at the End of the First Growing Season........................................................................ 30

4-1 Typha spp. Genotype Comparison: Above- and Belowground Dry Weight ......................................................................................... 43

4-2 Typha spp. Genotype Comparison: Shoot Density................................. 44 
$\underline{\text { Page }}$

2-1 Typha Excavation Study at Zim, MN: Analysis of Variance Summary Comparison of Planting Material........................................... 10

2-2 Typha Excavation Study at Zim, MN: Analysis of Variance Summary Comparison of Tissue Nutrient Concentration.......................... 13

2-3 Typha Excavation Study at Zim, MN: Soil Nutrient Concentration Means................................................................................................. 16

2-4 Typha Excavation Study at Zim, MN: Nutrient Standing Crop.............. 18

2-5 Typha Excavation Study at Zim, MN.......................................... 19

3-1 Typha Fertilization Study............................................................ 23

3-2 Typha Fertilization Study: Analysis of Variance Summary.................... 24

3-3 Significance of Fertilizer Treatment on Variables Affecting

Final Yield.................................................................................. 27

3-4 First Season Densities, Yields, and Nutrient Levels from Field Trials in 1980 and 1981 and from Natural Stand Surveys................................

3-5 First Season Tissue Element Concentrations from Field Trials in

1980 and 1981 and from Natural Stand Surveys............................... 34

3-6 Soil Information from Field Trials in 1980 and 1981 and from Natural Stand Surveys.................................................................... 35

4-1 Wetland Species Comparison: First Season Shoot Density and Aboveground Dry Weight........................................................................... 39

4-2 Wetland Species Comparison: Demonstration Plots.............................. 41

4-3 Summary of Wetland Species Standing Crop in Natural Stands............. 42

4-4 Typha Planting Stock Comparison.................................................... 45

4-5 Typha Genotype Comparison: Tissue Nutrient Concentrations at Final Harvest..................................................................................... 46

4-6 Typha spp. Yields from Selected Natural Stands in Minnesota............... 48 


\section{SUMMARY}

Emergent aquatic plants such as Typha spp. (cattails), Phragmites australis (reeds), and Scirpus spp. (rushes) have been identified as potential biomass crops. The high productivity of these plants coupled with the large amount of land potentially available for emergent aquatic production without competing with traditional agriculture has led to research into methods of emergent aquatics production in managed stands. The ultimate goal is the development of a management system which maximizes sustained yield while minimizing costly inputs and environmental degradation. This report focuses on first season results from studies of stand establishment and management, nutrient relationships, wetland species screening, and micropropagation.

\section{Stand Establishment and Management}

To determine the relative effectiveness of different planting material for Typha stand establishment, trial plots started with seed, seedlings, and rhizomes were compared. Stands established with rhizomes appear to be the most consistent and productive under a wide variety of conditions. Preliminary results indicate that stand establishment with seed results in relatively low first season yields; mature stands could probably be established within 2-3 years. Transplanting greenhouse-grown seedlings appears promising and may be particularly appropriate for establishing cutting beds of superior genotypes.

To test the feasibility of growing wetland crops on mined peatlands, two areas were excavated by removing $0.6 \mathrm{~m}$ and $1.5 \mathrm{~m}$ of peat. For comparative purposes, a third area was simply rotovated. Typha stands were successfully established on both excavated areas. After one growing season the most significant difference was in competitor control. Removing the seed bank by excavating is an effective, though costly, weed control method. The intermediate excavation $(0.6 \mathrm{~m})$ required the least amount of water control. Preliminary data indicate that when peat is removed mutrients may be less available under flooded conditions. Land preparation can have an effect on first season yields by altering the competitor seed bank, the availability of water, and mutrient availability.

\section{Typha Nutrient Experiments}

One component of production costs which significantly affects the final cost of any biomass resource is the mutrient input necessary to attain high, sustained yields. In the development of a new crop such as Typha, baseline numbers regarding nutrient requirements, patterns of nutrient uptake, and partitioning are needed. To begin to address these questions a large factorial experiment using three levels of nitrogen ( 0 , 75 , and $150 \mathrm{~kg} / \mathrm{ha})$, two levels of phosphorus $(0$ and $150 \mathrm{~kg} / \mathrm{ha})$ and two levels of potassium ( 0 and $300 \mathrm{~kg} / \mathrm{ha}$ ) designed to be followed for 2-3 years was established using Typha rhizomes. Results from the first season indicate that nutrients were not the limiting growth factor. Phosphorus and potassium applications resulted in a significant increase in shoot density and potassium application resulted in increased belowground dry weight. Fertilizer treatments were effective in significantly increasing tissue nutrient concentrations, nutrient standing crop, and soil fertility for phosphorus, potassium, and, in some cases, nitrogen. This will carry over into the second growing season, influencing both plant density and total yield. Owing to high nitrogen availability in newly cultivated organic soils, nitrogen losses through denitrification, and low early season nitrogen requirements, it may be more effective and less costly to apply nitrogen, if necessary, in mid-season. 
In comparing density, yield, and tissue nutrient concentrations from a wide range of experiments, and observations from natural stands, the following conclusions were reached:

- High biomass yields may be achievable with relatively low nutrient inputs.

- Management practices which optimize nutrient utilization and reduce luxury consumption must be developed.

- Shoot density and yield are highly correlated. A better understanding of the factors controlling shoot density is needed.

\section{Wetland Species Comparisons and Micropropagation}

Scirpus fluviatilis (rush), Sparganium eurycarpum (bur reed), Spartina pectinata (cordgrass), Carex atherodes (sedge), and Phragmites australis (reed) were identified as potential wetland biomass crops. These species were grown in $361.5 \mathrm{~m}^{2}$ paddies under identical conditions in order to compare such factors as plant density, above-and belowground dry weight, and tissue nutrient content after one and two years of growth. Demonstration plots of Phragmites, Scirpus, and Sparganium were also established on the excavated sites previously described. Scirpus attained the highest first season yields at $12.8 \mathrm{mt} / \mathrm{ha}$ (total dry weight) on the rotovated site at Zim, Minnesota. Sparganium, with a first year aboveground yield of $6.0 \mathrm{mt} / \mathrm{ha}$ in the paddy experiment and $6.7 \mathrm{mt} / \mathrm{ha}$ at Zim, also looks promising. Phragmites performed very poorly owing to problems with initial establishment.

A series of $361.5 \mathrm{~m}^{2}$ paddies containing Typha rhizomes collected from five productive natural stands and a commercial nursery were also established. In general, aboveground yields were within the range usually found in natural stands. The first season mean yield from the paddies planted with material from natural stands was $20.6 \mathrm{mt} / \mathrm{ha}$.

The objectives of the micropropagation study were to establish Typha explants in tissue culture, regenerate plantlets through shoot proliferation and/or callus redifferentiation, and finally, to establish those plantlets in conventional medium. After initial problems with contamination were overcome, a method of establishing explants in tissue culture using apical meristems and scape tissue was developed. Callus has been successfully produced in culture. Current work focuses on refining the conditions for callus generation and subsequent redifferentiation. 


\section{SECTION 1.0}

\section{GENERAL INTRODUCTION}

The possible use of wetlands to produce biomass energy crops is the focus of a research effort at the University of Minnesota. Wetlands dominated by Typha spp. (cattails) and other emergent vegetation, such as Phragmites (reeds) and Scirpus (rushes), are one of the most productive natural systems in the temperate zone (1). Minnesota, with over two million hectares of available peatland and 1.4 million additional hectares of available wet mineral soils, appears to have considerable potential for wetland crop production (Figure 1-1). Among the attractive features of this system is the fact that wetland crops would not compete with traditional crops for prime agricultural land. The use of peatlands for the production of a renewable resource also offers an attractive alternative to peat mining.

Its high yield potential and attractive chemical composition make Typha a particularly viable energy crop. The Minnesota research effort has demonstrated that total annual biomass yields between 25 and 30 dry tons/hectare are possible in planted stands (2). This compares with yields of total plant material between 9 and 16 dry tons/hectare in a typical Minnesota corn field. At least 50\% of the Typha plant is comprised of a belowground thizome system containing $40 \%$ starch and sugar (3). This high level of easily fermentable carbohydrate makes rhizomes an attractive feedstock for alcohol production. The aboveground portion of the plant is largely cellulose and although it is not as easily fermentable, it can be gasified or burned.

The high productivity of Typha can be rationalized in a number of ways. Of primary importance is the fact that cattails are not limited by the availability of water. Also, the canopy architecture appears to increase the efficiency with which directly incident and reflected sunlight can be utilized in photosynthesis. Because of the upright leaf angle in the foliage canopy, a greater proportion of the leaf area is exposed to direct sunlight. In contrast with most crop plants, Typha begins growth early in the spring from shoots developed the previous fall, and remains active until the leaves are killed by frost in the fall. Because of their adaptability to a wide range of temperatures, they are able to remain active through a greater proportion of the growing season. Each of these factors undoubtedly contributes to Typha's success as solar energy collector, but the relative importance of each has not as yet been carefully assessed.

The rate of Typha biomass accumulation is greatest, and almost constant, between June 15 and September 15. Thus, the decreasing day length through July and August appears to be compensated for by increased photosynthetic capacity as the foliage canopy develops. Growth rates during the period of maximum production average about 40 $\mathrm{g} / \mathrm{m}^{2} /$ day in agricultural soils (4), and about $30 \mathrm{~g} / \mathrm{m}^{2} /$ day in peat soils (5). Growth rates for agricultural crops of nearly $50 \mathrm{~g} / \mathrm{m}^{2} /$ day have been reported, but normally for only relatively short periods of two or three weeks. A growth rate of 30-40 $\mathrm{g} / \mathrm{m}^{2} /$ day sustained for a period of more than two months is unusual. Thus the high seasonal yields of cattails are due more to a prolonged moderate level of growth than to an unusually high spurt of photosynthetic activity.

Studies of Typha stand establishment and management, harvesting methods, equipment needs and design, environmental constraints, and the overall economics of wetland energy crop production are currently under way, administered by the University's Bio-Energy Coordinating Office (BECO). The major long-term objective of the multidisciplinary research program is to examine the possibility of developing an efficient and renewable 


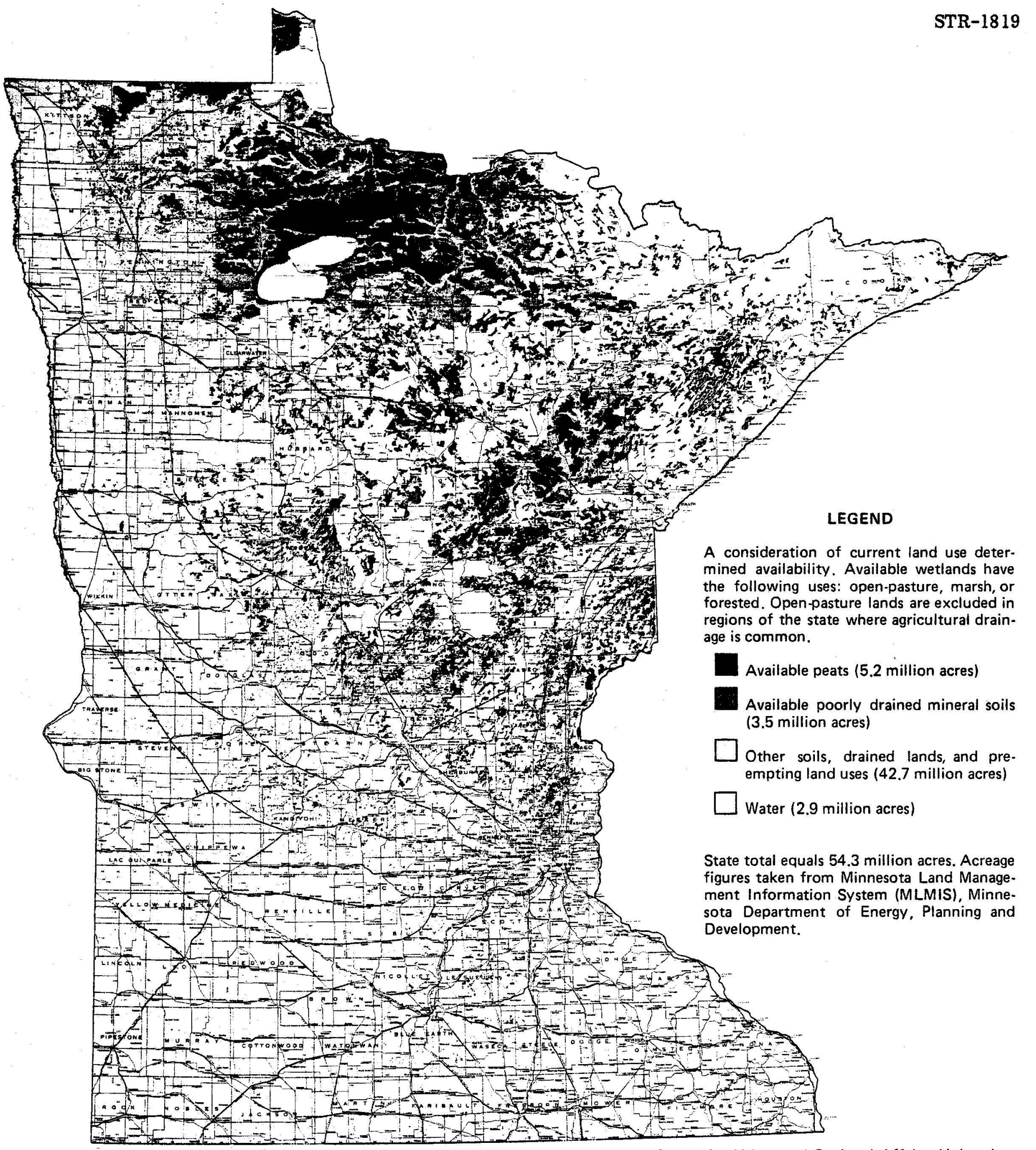

Produced by the Center for Urban and Regional Affairs, University of Minnesota, under contract with the Minnesota Energy Agency, November, 1981.

Figure 1-1. AVAILABLE WETLANDS FOR BIOENERGY PURPOSES LAND USE AND DRAINAGE CONSTRAINTS 
energy system in an environmentally sound fashion, using available indigenous resources. This report summarizes the first year results of a series of studies funded by the Solar Energy Research Institute (SERI). It is divided into the following sections:

- Typha Stand Establishment and Management

- Typha spp. Nutrient Experiments

- Wetland Species Comparisons and Micropropagation. 
SECTION 2.0

\section{TYPHA STAND ESTABLISHMENT AND MANAGEMENT}

\subsection{INTRODUCTION}

In order to establish large stands of Typha, it is necessary to investigate appropriate plenting material and land preparation. Because the plants are perennials, it is hoped that stand establishment need occur only once.

Planting material can be in the form of seed, seedlings, or rhizome pieces. Seed is by far the least costly method of establishment, but has problems of competition from weeds, slow first season growth, and low first season yields. Transplanting seedlings or rhizomes into fields results in rapid stand establishment and good first season yields, but has the disadvantage of high cost.

The effects of different land preparation schemes are being studied to aid in the selection of the best system for water and weed control, and to enhance information on the feasibility of using Typha to reclaim mined peatlands. Excavation and rotovation are the two major land preparations being investigated. The possibilities of chemical weed control are also being examined.

Weed control and water control are linked in that appropriate water levels during stand establishment limit the types of weeds which will grow. Different methods of land preparation will affect both the water regime and the weed concentration in a given area. Potential advantages of excavation are:

- reduction in the amount of water used for irrigation because of reduced seepage and closer proximity to ground water;

- elimination of dike maintenance;

- reduction in competitors resulting from removal of the surface seed bed;

- and, possible utilization of the excavated peat.

Considerable interest has developed in recent years in the mining of peatlands for energy production. This activity, if developed, would occur in a small but significant portion of the total wetland resource base if Department of Energy standards for fuel grade peat are followed. If mining does occur, biomass production appears to be an attractive method of reclamation. Since excavated peatlands would be too wet for most terrestrial plants unless extensive drainage systems were developed, emergent aquatic species appear to be particularly appropriate for biomass production.

\subsection{PLANTING MATERIAL AND METHODS}

\subsubsection{Objective}

The objective of this research is to determine the relative effectiveness of different planting material for Typha stand establishment (seed, seedling, or rhizome), and the most efficient procedure for preparing and planting each of these. 


\subsubsection{Methods}

\subsubsection{Seed}

Typha latifolia and Typha angustifolia seed heads were collected and processed according to the methods of Pratt et al (5). Cleaned seed was stored dry, at room temperature, for one year prior to planting.

Plots were dry seeded at Aitkin in June using a "cyclone" spreader. Seed was mixed with an inert substance (farina) to increase volume and achieve a seeding rate of 700 seeds $/ \mathrm{m}^{2}$. The area was flooded the next day and the water level generally was maintained at 3 to $15 \mathrm{~cm}$ for the season.

In August, plots at Aitkin were hydro-seeded using a modified compressed air sprayer. The seed was soaked in water and exposed to full sunlight for four hours prior to seeding. Seed was then mixed with a viscous agar solution to keep it uniformly suspended, and seeded at a rate of $700 / \mathrm{m}^{2}$ onto a flooded field. The area remained flooded with at least $3 \mathrm{~cm}$ of water for the rest of the season.

\subsubsection{Seedling}

Seeds from Zim and St. Paul seed stock were started in the greenhouse in flats on April 1, 1981. The soil (an organic loam from the Forest Lake area) was kept saturated and was fertilized periodically with Peters 20-20-20. At the end of April the seedlings from Zim seed stock were transplanted into peat pellets. The St. Paul stock seedlings were transplanted to peat pellets in mid-May.

Three sets of plots were prepared for planting with seedlings and rhizome pieces at Zim. For one set of plots, the soil surface was rotovated prior to planting. For another set, $0.6 \mathrm{~m}$ of peat was removed and for a third $1.5 \mathrm{~m}$ was removed, leaving approximately $0.6 \mathrm{~m}$ of peat on top of the mineral base (Figure 2-1). Seedlings from Zim seed stock were hand planted in late May at a density of $9 / \mathrm{m}^{2}$.

At Aitkin, seedlings from Zim and St. Paul seed stock were planted on a rotovated mineral soil in mid-June. These seedlings were planted using a mechanical transplanter at a density of $4 / \mathrm{m}^{2}$.

\subsubsection{Rhizome}

Plots were established from rhizomes at Zim under the three sets of land preparation conditions described above. Other plots were established from rhizomes at Aitkin on an organic clay soil and in paddies at St. Paul (see Section 4.0).

The rhizome pieces planted at Zim and St. Paul were harvested from natural stands shortly before they were needed for planting. In the interim (two days to three weeks), they were stored in plastic bags in a cold room. Only rhizome pieces with visible buds were stored and used for planting stock. The rhizome pieces were hand planted at Zim and St. Paul.

The plots at Aitkin were planted on an organic clay soil using rhizome pieces purchased through Kester's Wild Game Food Nurseries, Inc. (Omro, Wisconsin). Many of these 
(HORIZONTAL AXIS NOT TO SCALE)

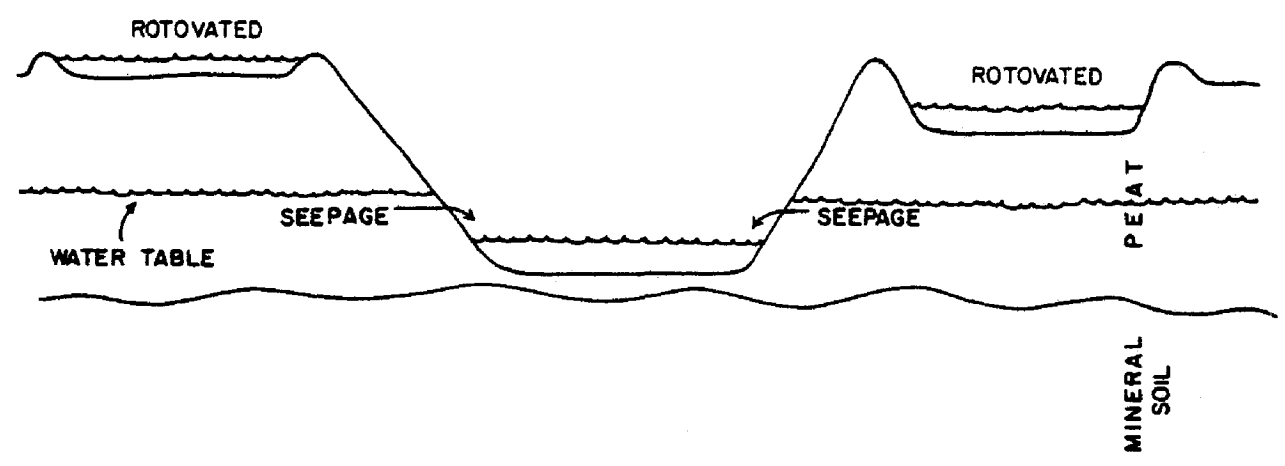

Figure 2-1. EXCAVATION SCHEME - ZIM, MINNESOTA 
pieces were small and had no visible buds. It is unknown how long and under what conditions the rhizomes had been stored after harvesting.

\subsubsection{Results and Discussion}

\subsubsection{Seed}

Mixed results have been obtained in establishing Typha stands from seed. Test plots at $\mathrm{Zim}$, seeded in May 1980, yielded between 3.3 and $7.7 \mathrm{mt} / \mathrm{ha}$ (6). The areas seeded at Aitkin had an average total yield of $0.5 \mathrm{mt} / \mathrm{ha}$. The higher yields at Zim are more in accordance with preliminary studies done in artificial paddies at St. Paul (5).

There are several factors which could explain the relatively low yields at Aitkin. One factor is competition from weeds. The plots at Zim had fewer competitors overall, and it was found that competitor aboveground standing crop was negatively correlated with Typha aboveground standing crop (6). By mid-August 1981, the Aitkin site was covered with barnyard grass (Echinochloa crussgalli). The difference in competitor population cannot be accounted for solely on the besis of site preparation. The Aitkin site was rotovated before planting, but had a much greater weed problem than sites similarly prepared at Zim.

Another possible contributing factor to the yield difference is water control. The areas at $\mathrm{Zim}$ were maintained in a saturated condition until mid-August at which time they were flooded. The areas at Aitkin were flooded immediately after seeding and maintained that way most of the time through the course of the summer. Preliminary greenhouse and growth chamber experiments have since indicated that seed germination and early seeding survival are enhanced under mud flat rather than flooded conditions. Further studies are needed to verify this.

One final difference between the Aitkin and Zim studies which might account for yield differences is soil type and fertility. The Zim study was carried out on a peat soil fertilized with $1250 \mathrm{~kg} / \mathrm{ha} 6-24-24,25 \mathrm{~kg} / \mathrm{ha} \mathrm{CuSO}_{4}$, and $100 \mathrm{~kg} / \mathrm{ha}$ Peters Fritted Trace elements. The site at Aitkin was a mineral soil fertilized with $1250 \mathrm{~kg} / \mathrm{ha} 6-12-24$ and no micronutrients. Fall soil reports showed no difference between the available phosphorus and potassium content of the two soils, but unfortunately nitrogen and micronutrient data are currently unavailable.

Three methods have been tried for establishing stands by seed. Andrews et al (6) applied a seed/water mix to the soil using a squirt bottle. This method is inexact since the seeds do not stay evenly suspended in the water, and would be too slow for large scale seeding.

Application of dry seed worked well at Aitkin on a mineral soil, but success in establishing a stand by this method was variable. This may be the result of problems discussed above or problems with 1) seed movement when the field was flooded, 2) poor light quantity or quality after flooding, or 3) low soil/water temperatures.

Using a sprayer to apply seed suspended in a viscous solution looks promising because it: 1) achieves an even application of seed, 2) allows seed to be pretreated with light and water for improved germination, and 3) can be done on a flooded field reducing problems associated with soil disturbance. Agar has been used successfully as the viscous medium, but other less expensive media (e.g., gelatin) should be tested. 


\subsubsection{Seedling vs. Rhizome Planting Material Comparison}

Within each of the three land preparation areas at the Zim 1981 research site, rhizome and seedling planted plots were compared in terms of yield and tissue nutrient differences. This provided a replicated comparison of the two planting materials at the three different peat depths.

The rotovated (unexcavated) area showed a significantly higher yield in plots planted with rhizomes than in seedling plots (Table 2-1, Figure 2-2), although there was no significant difference in shoot density (Table 2-1, Figure 2-3). The seedling areas also showed significantly higher tissue nutrient concentrations than rhizome planted areas (Table 2-2).

Most of the plants in the seedling plots of the unexcavated area were dead at the time of harvest, and were quite small. A hail storm which came soon after planting this area, along with early season frost conditions, and perhaps increased susceptibility to insect damage, all possibly acted together to kill the seedlings. Whatever the cause, the fact that most of the seedlings died before they grew appreciably probably accounts for the elevated nutrient condition. Most plants take up nutrients rapidly in the early grow th stages, and the nutrient concentration is then diluted as dry matter is increased during a period of slowed nutrient uptake. In that sense, the nutrient and yield data from the unexcavated area are probably not typical of a comparison between rhizome and seedling as planting material for Typha stand establishment. On the other hand, it does point out the greater vulnerability of seedling planted plots to hostile environmental conditions.

In the $0.6 \mathrm{~m}$ excavated area, the total yield in the rhizome planted areas was significantly higher than the seedling plots (Table 2-1, Figure 2-2), although the shoot densities were not significantly different (Table 2-1, Figure 2-3). In the $1.5 \mathrm{~m}$ excavated area, there was no significant yield difference, but the seedling planted plots had a significantly higher shoot density at the end of the season (Table 2-1, Figure 2-3). The rhizome planting material produced larger plants at all excavation depths.

It is interesting to note that the aboveground and belowground tissue macronutrient concentration is generally not significantly different between rhizome and seedling planted areas (Table 2-2). Any stand es tablishment scheme which would increase nutrient concentration in aboveground tissue would cause an undesirable removal of more nutrients from the system at harvest. Increased concentration in belowground tissue, conversely, would be more desirable, particularly in situations where repeated aboveground harvest is intended.

Some tissue micronutrient concentrations tended to be higher in aboveground tissue of seedling established plots and higher in belowground tissue of rhizome planted plots in the $0.6 \mathrm{~m}$ and $1.5 \mathrm{~m}$ excavated areas. This varied between micronutrients, and no pattern was obvious.

Both rhizome pieces and seedlings have been successfully planted using a mechanical transplanter. Seedlings are somewhat easier to mechanically transplant because of uniformity of size and orientation. Seedlings need to be larger for mechanical planting than would be required if planted by hand. 
Table 2-1. TYPHA EXCAVATION STUDY AT ZIM, MN ANALYSIS OF VARIANCE SUMMARY COMPARISON OF PLANTING MATERIAL

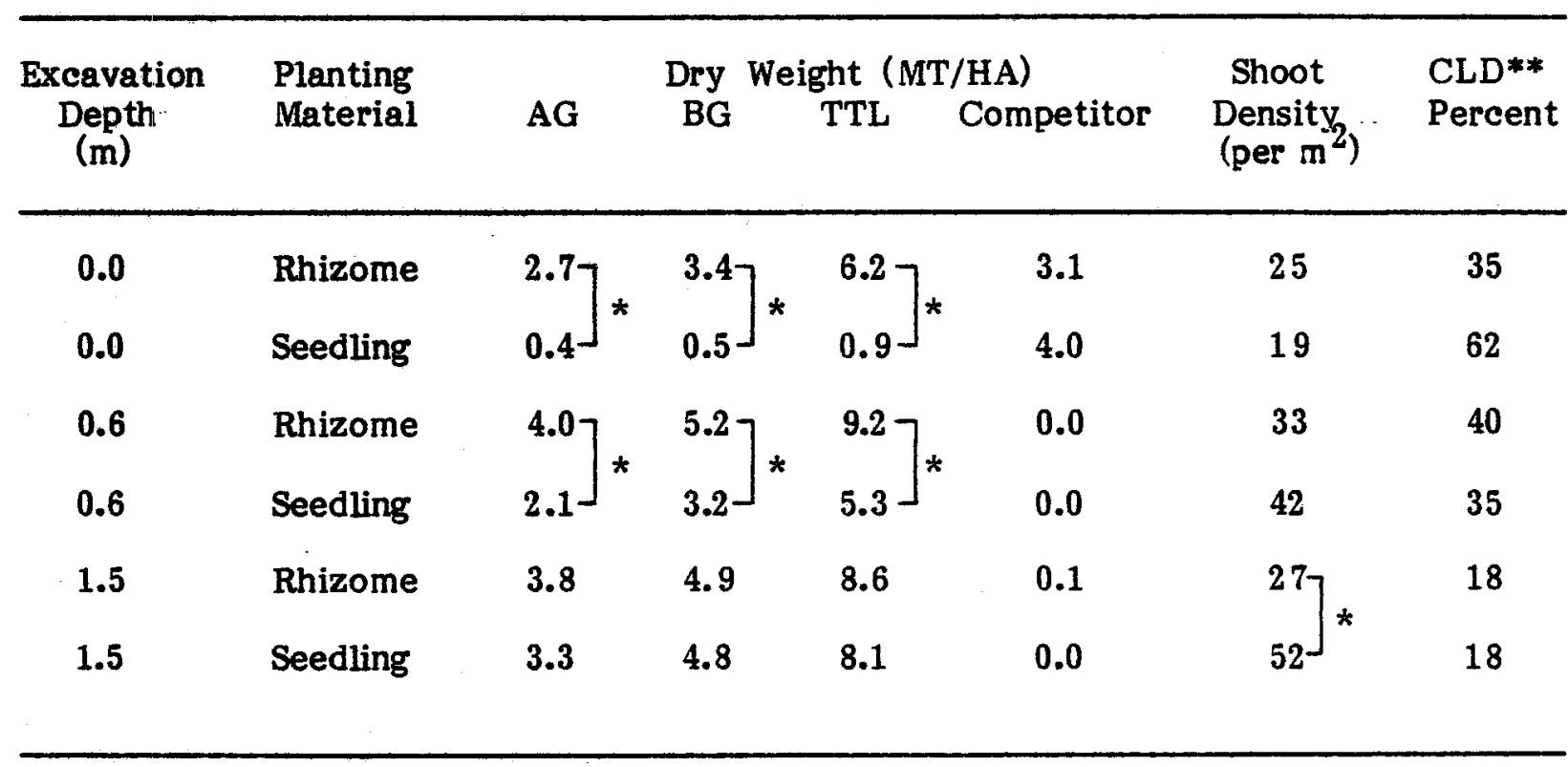

$A G$ = aboveground

$B G$ = belowground

TTL $=$ total

Note: Values represent means of four plots.

*Significant difference at $\alpha=0.05$.

**CLD percent is the percentage of shoots exhibiting any sign of insect-caused central leaf damage. 


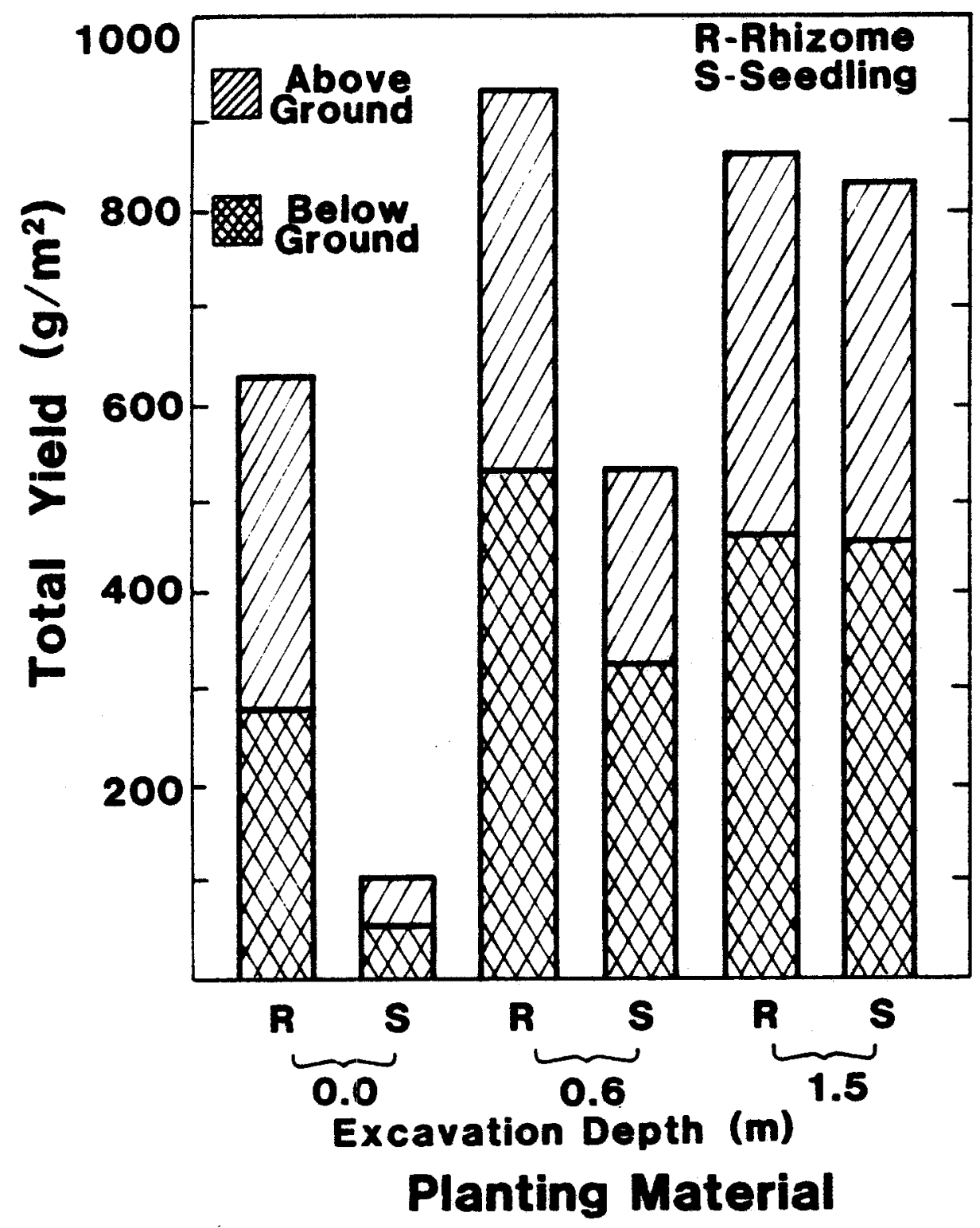

Figure 2-2. FIRST YEAR TYPHA YIELDS AS AFFECTED BY LAND PREPARATION AND PLANTING MATERIAL 


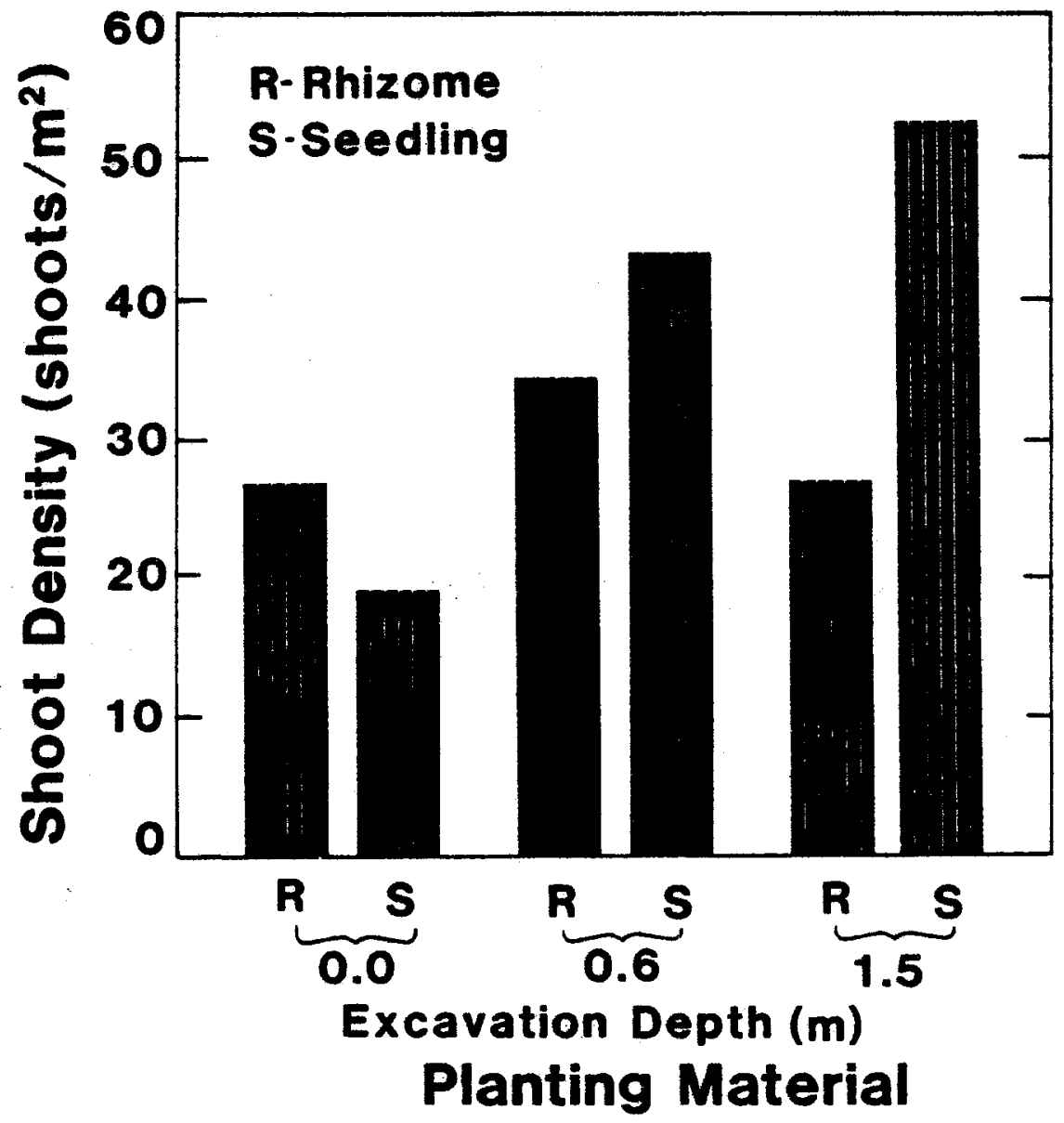

Figure 2-3. FIRST YEAR TYPHA SHOOT DENSITY AS AFFECTED BY LAND PREPARATION AND PLANTING MATERIAL 
Table 2-2. TYPHA EXCAVATION STUDY AT ZIM, MN ANALYSIS OF VARIANCE SUMMARY

COMPARISON OF TISSUE NUTRIENT CONCENTRATION

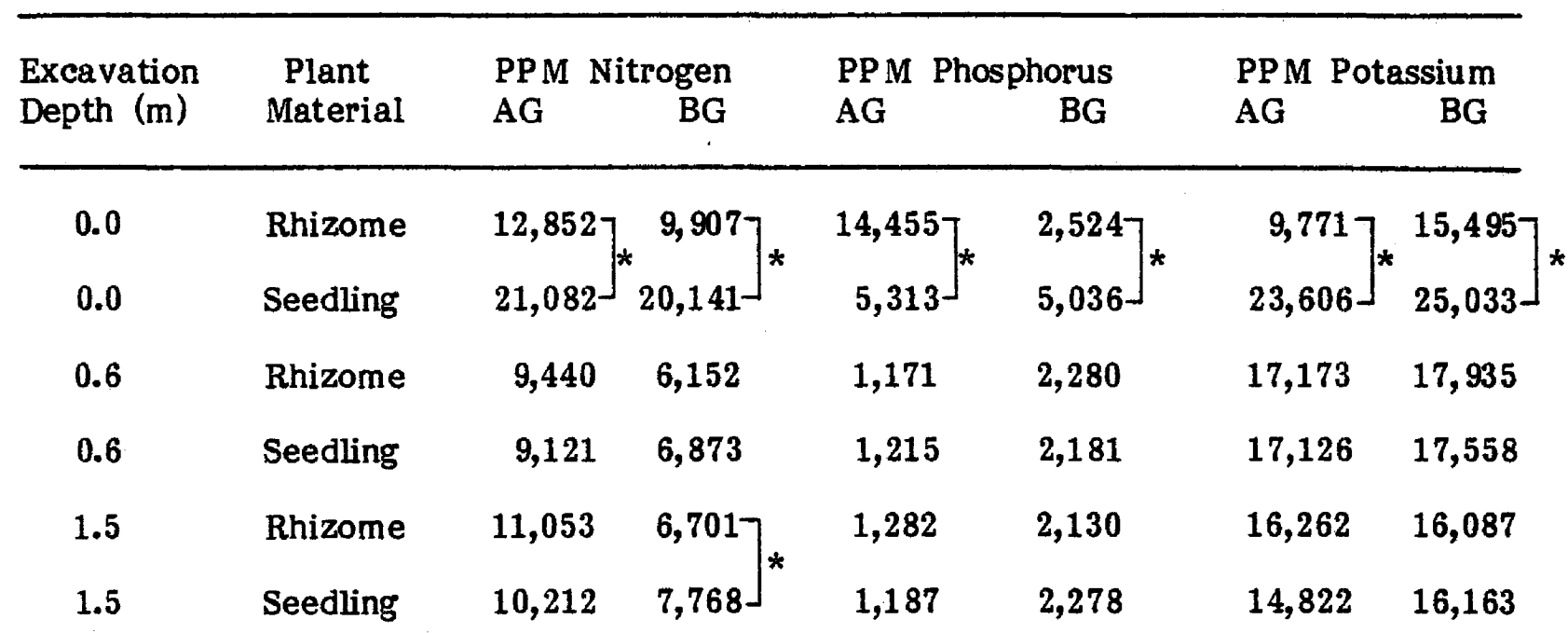

$A G=$ aboveground

$\mathrm{BG}=$ belowground

Note: Values represent means of four plots. Samples were taken in early October. *Significant difference at $\alpha=0.05$. 


\subsubsection{Overview of Field Research}

Over the course of two years of field research and from previous paddy and natural stand studies, some general trends have emerged concerning stand establishment using the three different planting materials.

Stands established from seed tend to be very dense with short, small plants present after the first year. This has generally resulted in lower yields (6), although yields of up to $12.3 \mathrm{mt} /$ ha have been obtained in the first year with seeded paddies (5). Whether the yields are high or low, the ratio of density to yield has been consistently higher in seeded stands than seedling or rhizome established stands. Data from the Aitkin mineral site demonstrate this trend. The seeded plots on this site had a mean ratio of $\mathbf{0 . 5 0}$. The mean shoot density to yield ratio of the seedling area was 0.12 .

Data from natural stands suggest that the same relationships hold there. Some collected observations from natural stands in the North Central United States (6) showed a range of densities from 28 to 79 shoots $/ \mathrm{m}^{2}$ for mature, established stands. One observation was made of a year old stand which was naturally established from seed. This stand had a density of 557 shoots $/ \mathrm{m}^{2}$. The aboveground standing crop was $672 \mathrm{~g} / \mathrm{m}^{2}$, whereas the mature stands ranged from $378-2320 \mathrm{~g} / \mathrm{m}^{2}$.

It is not clear what these observations mean for stand establishment by seed. Highly variable germination rates and problems with uniform stand establishment have necessitated the high seeding rates used. Until a more reliable method is established, some form of density control, other than lowering the seeding rate, might be used as needed. Second and third year data are needed to determine if a seeded stand will thin itself naturally and achieve better yields (as natural stand data would tend to indicate), or if seeded plots need to be thinned in the first year to increase productivity.

Another trend has emerged which indicates that under the same set of circumstances, rhizome planted plots tend to be slightly, though not always significantly, more productive than seedling established plots (Table 2-1, Figure 2-2). This is not unexpected since rhizomes contain larger carbohydrate and nutrient reserves than seedlings which should result in more rapid early season growth in rhizome planted stands. Also, as was noted earlier, seedlings appear to be more susceptible to pests and environmental damage than rhizome pieces.

Stand establishment by planting rhizome pieces has been successfully attempted under a wide range of conditions. Thirty-six plots were established in aboveground paddies at St. Paul using different rhizome sources for planting material (see Section 4.0). Total yields at this location ranged from 13.1 to $23.0 \mathrm{mt} / \mathrm{ha}$. Rhizome plots at Zim in 1980 ranged from a low of $0.9 \mathrm{mt} / \mathrm{ha}$ in plots established with no land preparation or fertilizer to $15.6 \mathrm{mt} / \mathrm{ha}$ in plots densely planted $\left(25 / \mathrm{m}^{2}\right)$ on a rotovated, fertilized site (6). An 0.2 ha research site at Aitkin was planted with rhizome pieces and showed first season yields ranging from 1.5 to $14.5 \mathrm{mt} / \mathrm{ha}$.

Stand establishment with seedlings has been attempted fewer times, so information on success of the method under a wide range of conditions is lacking. One site other than the rhizome/seedling comparison site at Zim was established with seedlings at Aitkin in 1981 . The yields at this site ranged from 0.7 to $2.7 \mathrm{mt} / \mathrm{ha}$, , considerably lower than most research plots established with rhizomes. 


\subsubsection{Conclusions}

- Stands established by rhizomes appear to be the most consistent and productive under a wide variety of conditions in the field and in paddies.

- More attempts at seedling stand establishment are needed to make a fair comparison to other methods because only one year's data are available for seedling trials.

- Further investigation is needed into water level control and whether or not density control is necessary for consistent stand establishment by seed. Perfecting this method would be important because seed is more readily available and less expensive than other planting materials.

\subsection{LAND PREPARATION}

\subsubsection{Objectives}

- Test the feasibility of growing wetland crops on areas that have had varying amounts of peat removed to simulate reclamation of mined peatlands.

- Investigate the effects of different land preparation schemes on productivity, and weed and water control.

\subsubsection{Methods}

Plots were prepared at $\mathrm{Zim}$ as described under "seedling" and "rhizome" methods in Subsection 2.2.2. The three different land preparation areas were fertilized identically at a rate of $1250 \mathrm{~kg} / \mathrm{ha} 6-12-24,70 \mathrm{~kg} / \mathrm{ha}$ Peters Fritted Trace elements and $20 \mathrm{~kg} / \mathrm{ha}$ $\mathrm{CuSO}_{4} \cdot$

Plants were checked for damage from the moth Arzama obliqua at harvest, since the stem boring larvae has been identified as a potential Typha pest (6).

\subsubsection{Results and Discussion}

\subsubsection{Soil Nutrient Profile}

The excavation study at Zim illustrated some soil differences which might occur lower in the soil profile when the overlying peat is mined. Before fertilization, available phosphorus and potassium were considerably lower in the areas excavated to $0.6 \mathrm{~m}$ and $1.5 \mathrm{~m}$ than in the unexcavated area (Table 2-3). The same fertilizer was applied to all areas, yet at the end of the season, available phosphorus and potassium had been boosted above the spring levels in the two excavated areas, but remained about the same in the unexcavated area.

This differential accumulation of phosphorus and potassium in the soil cannot be attributed to more of these nutrients being removed by plants in the unexcavated area. 
Table 2-3. TYPHA EXCAVATION STUDY AT ZIM, MN

SOIL NUTRIENT CONCENTRATION MEANS*

\begin{tabular}{|c|c|c|c|c|c|c|c|c|c|c|}
\hline \multirow{2}{*}{$\begin{array}{l}\text { Excavation } \\
\text { Depth }\end{array}$} & \multicolumn{10}{|c|}{ Parts per Million } \\
\hline & $\longdiv { P }$ & $\bar{K}$ & $\overline{\mathrm{Ca}}$ & $\mathrm{Mg}$ & $\mathrm{Fe}$ & $\mathrm{Mn}$ & $\mathrm{Zn}$ & $\mathrm{Cu}$ & $\mathrm{B}$ & $\mathrm{pH}$ \\
\hline \multicolumn{11}{|l|}{$0.0 \mathrm{~m}$} \\
\hline $\begin{array}{l}\text { Spring ** } \\
\text { Fall** }\end{array}$ & $\begin{array}{l}67 \\
62\end{array}$ & $\begin{array}{l}120 \\
116\end{array}$ & $\begin{array}{l}18,278 \\
17,951\end{array}$ & $\begin{array}{l}2,741 \\
2,727\end{array}$ & $\begin{array}{r}10,443 \\
9,436\end{array}$ & $\begin{array}{l}556 \\
520\end{array}$ & $\begin{array}{l}36 \\
72\end{array}$ & $\begin{array}{r}9 \\
27\end{array}$ & $\begin{array}{l}0 \\
3\end{array}$ & $\begin{array}{l}5.5 \\
5.7\end{array}$ \\
\hline \multicolumn{11}{|l|}{$0.6 \mathrm{~m}$} \\
\hline $\begin{array}{l}\text { Spring } \\
\text { Fall }\end{array}$ & $\begin{array}{l}12 \\
44\end{array}$ & $\begin{array}{l}21 \\
73\end{array}$ & $\begin{array}{l}13,874 \\
15,237\end{array}$ & $\begin{array}{l}2,329 \\
2,410\end{array}$ & $\begin{array}{l}5,875 \\
6,920\end{array}$ & $\begin{array}{l}339 \\
368\end{array}$ & $\begin{array}{l}56 \\
64\end{array}$ & $\begin{array}{l}61 \\
31\end{array}$ & $\begin{array}{l}1 \\
2\end{array}$ & $\begin{array}{l}5.2 \\
5.6\end{array}$ \\
\hline \multicolumn{11}{|l|}{$1.5 \mathrm{~m}$} \\
\hline $\begin{array}{l}\text { Spring } \\
\text { Fall }\end{array}$ & $\begin{array}{l}10 \\
93\end{array}$ & $\begin{array}{l}14 \\
75\end{array}$ & $\begin{array}{l}12,833 \\
13,356\end{array}$ & $\begin{array}{l}2,023 \\
2,067\end{array}$ & $\begin{array}{l}6,337 \\
6,162\end{array}$ & $\begin{array}{l}248 \\
257\end{array}$ & $\begin{array}{l}19 \\
47\end{array}$ & $\begin{array}{l}12 \\
30\end{array}$ & $\begin{array}{l}0 \\
1\end{array}$ & $\begin{array}{l}5.3 \\
5.4\end{array}$ \\
\hline
\end{tabular}

* Mean of three samples from each excavation depth at each time of year. **Spring samples were taken before fertilization. Fall samples were taken in October. 
In fact, the most potassium and phosphorus were removed by plants in the $1.5 \mathrm{~m}$ area, followed by the $0.6 \mathrm{~m}$ area with the least being removed in the unexcavated area (Table 2-4).

Micronutrient concentrations in the soil before fertilization also tended to be lower in the excavated areas (Table 2-3) except for zinc and copper. Fertilization seemed to boost the micronutrient levels in most cases, although the soil in the excavated areas remained lower in micronutrients than the unexcavated area. The $\mathrm{pH}$ was approximately the same at all excavation depths (Table 2-3).

\subsubsection{Management Considerations}

Each method of land preparation at the Zim research site offers a different set of management considerations. Previous work done at Zim in 1980 (6) also offers an analysis of the effects of different land preparation methods. The methods considered in 1980 were: 1) no preparation except to remove shrubs, 2) rotovation, and 3) removal of $0.2 \mathrm{~m}$ of peat.

One dramatic result of these different land preparation methods is the difference that is observed in the number of competitors. The aboveground standing crop of competitors averaged $300 \mathrm{~g} / \mathrm{m}^{2}$ on the unrotovated area at the $1980 \mathrm{Zim}$ site, and $350 \mathrm{~g} / \mathrm{m}^{2}$ on the rotovated area at the 1981 site (Table 2-5). Rotovation produced better results at the 1980 site with competitor dry weight averaging from 80 to $190 \mathrm{~g} / \mathrm{m}^{2}$. At both sites the competitor aboveground standing crop dropped below $10 \mathrm{~g} / \mathrm{m}^{2}$ with peat removal (Table 2-5).

At both the 1980 and the 1981 research sites and in plots established with all three planting materials, competitor aboveground standing crop is negatively correlated with Typha yield. In other words, decreased yields are associated with competitor problems, and competitors are generally eliminated by removing the top surface of the soil which contains a viable seed bank. No difference in weed control was found by removing more soil; the $0.2 \mathrm{~m}$ excavation at $\mathrm{Zim}$ in 1980 had as few weeds as the $1.5 \mathrm{~m}$ excavation in 1981.

Insect damage from the stem boring larvae of Arzama obliqua does not appear to be correlated with land preparation technique. At the 1981 Zim research site, the percent of insect damage was greatest in the unexcavated area and least for the $1.5 \mathrm{~m}$ excavated area for seedling planted plots (Table 2-5). This relationship did not hold for the rhizome planted plots or the rhizome planted and seeded plots at the 1980 Zim site (6). The large insect population in the seedling plots of the unexcavated area probably is related to the weakness of the seedlings resulting from harsh early season weather conditions.

The research sites at Aitkin and St. Paul showed no evidence of damage from A. obliqua. Previous natural stand studies also revealed little damage from these stem borers. It is unknown what conditions are conducive to damage, but it is a management consideration that needs to be dealt with since the insect can significantly reduce yields (Table 2-5) (6).

Water control requirements are very different with varying land preparation schemes because of the close proximity of the water table to the surface in a wetland. The water level in the $1.5 \mathrm{~m}$ excavated area had to be pumped down frequently whereas 
Table 2-4. TYPHA EXCAVATION STUDY AT ZIM, MN NUTRIENT STANDING CROP

\begin{tabular}{cccccc}
\hline $\begin{array}{c}\text { Excavation } \\
\text { Depth }(\mathrm{m})\end{array}$ & $\begin{array}{c}\text { Total Plant } \\
\text { Nitrogen } \\
\left(\mathrm{g} / \mathrm{m}^{2}\right)\end{array}$ & $\begin{array}{c}\text { Total Plant } \\
\text { Phosphorus } \\
\left(\mathrm{g} / \mathrm{m}^{2}\right)\end{array}$ & $\begin{array}{c}\text { Total Plant } \\
\text { Potassium } \\
\left(\mathrm{g} / \mathrm{m}^{2}\right)\end{array}$ & $\begin{array}{c}\text { Total } \\
\text { Yield } \\
\left(\mathrm{g} / \mathrm{m}^{2}\right)\end{array}$ & $\begin{array}{c}\text { Shoot Density } \\
\left(\mathrm{shoots} / \mathrm{m}^{2}\right)\end{array}$ \\
\hline 0.0 & 4.3 & 0.8 & 4.8 & 354 & 22 \\
0.6 & 5.5 & 1.3 & 12.6 & 724 & 38 \\
1.5 & 7.3 & 1.5 & 13.3 & 838 & 39 \\
\hline
\end{tabular}

Note: Values represent means of eight plots. Samples were taken in early October. 
Table 2-5. TYPHA EXCAVATION STUDY AT ZIM, MN

\begin{tabular}{ccccccc}
\hline $\begin{array}{c}\text { Excavation } \\
\text { Depth } \\
(\mathrm{m})\end{array}$ & $\begin{array}{c}\text { Planting } \\
\text { Material }\end{array}$ & $\begin{array}{c}\text { Shoot Density } \\
\text { (per } \mathrm{m}^{2} \text { ) } \\
\text { Mean }\end{array}$ & $\begin{array}{c}\text { Mean CLD } \\
\text { Percent* }\end{array}$ & $\begin{array}{c}\text { Mean Competitor } \\
\text { Dry Weight } \\
\text { (mt/ha) }\end{array}$ & $\begin{array}{c}\text { Total } \\
\text { Yield } \\
\text { (mt/ha) }\end{array}$ \\
\hline 0.0 & Rhizome & 25 & $15-31$ & 35 & 3.1 & 6.2 \\
0.6 & Rhizome & 33 & $29-41$ & 40 & 0.0 & 9.2 \\
1.5 & Rhizome & 27 & $24-32$ & 18 & 0.1 & 8.6 \\
0.0 & Seedling & 19 & $6-32$ & 62 & 4.0 & 0.9 \\
0.6 & Seedling & 42 & $36-48$ & 35 & 0.0 & 5.3 \\
1.5 & Seedling & 52 & $44-56$ & 18 & 0.0 & 8.1 \\
\hline
\end{tabular}

*Mean CLD Percent $=\%$ of shoots exhibiting any sign of insect-caused central leaf damage. 
the unexcavated areas needed regular irrigation. This would probably hold true in most drained wetlands. At the $1980 \mathrm{Zim}$ site, the water table was high enough to keep even the unexcavated areas saturated most of the time without adding any additional water. Water did have to be pumped in to flood the area, however.

\subsubsection{Conclusions}

- Typha stands can be successfully established on areas that have had varying amounts of peat removed.

- Preliminary data indicate that nutrients may be less available when significant amounts of peat are removed in some locations. Different peat soils would have to be studied to determine if this is a general principle.

- Competitors can pose a significant threat to Typha stand establishment in the first year. Removing the seed bank by excavating appears to be effective in controlling weeds, but other weed control measures, such as early flooding or chemical applications, need to be investigated since excavation can often be impractical and costly.

- Water availability and cost, and the level of the water table, should be considered in choosing a land preparation scheme for Typha stand establishment.

- Land preparation can have an effect on yields of first year stands by altering nutrient availability, the competitor seed bank, and the availability of water. 


\title{
SECTION 3.0
}

\author{
TYPHA SPP. NUTRIENT EXPERIMENTS
}

\subsection{INTRODUCTION}

The selection of cattail (Typha spp.) as a candidate for a bioenergy crop was based on a number of factors described in the introduction of this report. The high productivity of these plants in natural stands coupled with the low opportunity costs of land which could be used to grow them has led to research into methods of production in newly established, managed stands. The ultimate goal is to determine a management system which maximizes yield and minimizes inputs resulting in an energy resource that is economically competitive with other renewable and non-renewable energy resources.

One component of production costs which could significantly affect the final cost of this resource is that of nutrients required to attain high yields. In a natural system, nutrient recycling greatly reduces the need for additional nutrient inputs. In a bioenergy production system, nutrients are removed from the system when the biomass is harvested. High, sustained yields require that these nutrients be replaced. This can be accomplished to varying degrees by natural biological and physical processes and by application of fertilizers. The actual amounts and types of nutrients which need to be replaced through fertilizer application will depend on how much is replaced by natural processes and the overall nutrient requirements of Typha.

In agronomic crops, nitrogen, phosphorus, and potassium are the macronutrients of major concern because of their cost and effect on yield. This will, no doubt, also be the case for Typha production. In addition to these macronutrients, other macro- and micronutrients could prove to be limiting, especially in the anaerobic organic soils where cattails will be grown. Copper is an example of a micronutrient often found limiting in organie soil (7).

The need, then, exists to determine the following information for Typha in a field situation:

- The nutrient requirements needed to achieve high yields

- How nutrients affect yield and the partitioning of yield into above- and belowground components

- How to minimize the nutrient input by avoiding unnecessary losses of fertilizer through luxury consumption, denitrification, or other processes.

- What amount of nutrients are removed from the system during harvest.

It is important to note that nutrients are only one component affecting yield. Planting stock, density, competition from weeds, and other factors including temperature, soil conditions, and insects all influence yield. It is also important to note that results presented here are first season results from which conclusions must be interpreted cau tiously. 


\subsection{EFFECT OF NITROGEN, PHOSPHORUS, AND POTASSIUM ON FIRST SEASON YIELD}

\subsubsection{Objectives}

- Determine the effect of different combinations of nitrogen, phosphorus, and potassium on first and second season yields and the partitioning of these yields into above- and belowground components.

- Determine the effect of different combinations of nitrogen, phosphorus, and potassium on factors affecting yield including density, competitors, and tissue nutrient concentration.

- Determine the effect of different combinations of nitrogen, phosphorus, and potassium on soil fertility and nutrient standing crop over the course of two growing seasons.

- Gather information on Typha spp. nutrient requirements other than nitrogen, phosphorus, or potassium.

\subsubsection{Methods}

A 0.5 ha paddy with a well-decomposed organic soil was used for the study. Prior to use by this project, the land was uncultivated.

The experimental design was a blocked complete factorial experiment with three levels of nitrogen $(0,75$, and $150 \mathrm{~kg} / \mathrm{ha})$, two levels of phosphorus ( 0 and $150 \mathrm{~kg} / \mathrm{ha})$, and two levels of potassium ( 0 and $300 \mathrm{~kg} / \mathrm{ha}$ ). The nitrogen was applied as urea to slow down the denitrification process, and all fertilizers were incorporated to a depth of $10-15 \mathrm{~cm}$.

Commercially obtained planting stock consisting of rhizome pieces and shoot bases was used to plant each of $483 \mathrm{~m} \times 5 \mathrm{~m}$ plots at a density of $9 / \mathrm{m}^{2}$. Planting occurred in mid-May and replanting portions of each plot occurred in mid-June. Replanting was necessary because of the low survival rate of initial planting stock.

The field was flooded to an average depth of $12 \mathrm{~cm}$ during the growing season.

\subsubsection{Results and Discussion}

Results showing average first season dry weights and shoot densities for each of the twelve fertilizer treatments are shown in Table 3-1. The range of dry weights and shoot densities is also shown. Shoot densities ranged from 11 to $48 / \mathrm{m}^{2}$; dry weights ranged from 1.5 to $14.5 \mathrm{mt} / \mathrm{ha}$. An analysis of variance which was run on this data indicates that some of the differences in yield and density can be attributed to fertilizer treatment. A summary of this analysis is shown in Table 3-2. Although there is a trend toward increased yields and densities with increasing fertilizer rates, this trend is statistically significant only in the cases of phosphorus and density, potassium and density, and potassium and belowground dry weight. 
Table 3-1. TYPHA FERTILIZATION STUDY

\begin{tabular}{|c|c|c|c|c|c|c|c|c|c|c|}
\hline \multirow{2}{*}{\multicolumn{3}{|c|}{$\begin{array}{c}\text { Fertilizer } \\
\text { Rate } \\
\text { (kg/ha) }\end{array}$}} & \multirow{2}{*}{\multicolumn{2}{|c|}{$\begin{array}{c}\text { Shoot } \\
\text { Density } \\
\left(\text { per } \mathrm{m}^{2}\right)\end{array}$}} & \multicolumn{6}{|c|}{ Dry Weight (mt/ha) } \\
\hline & & & & & \multicolumn{2}{|c|}{ Aboveground } & \multicolumn{2}{|c|}{ Belowground } & \multicolumn{2}{|c|}{ Total } \\
\hline $\mathbf{N}$ & $\mathbf{P}$ & $\mathbf{K}$ & Mean & Range & Mean & Range & Mean & Range & Mean & Range \\
\hline 0 & 0 & $\mathbf{0}$ & 22 & $14-28$ & 2.71 & $1.38-4.79$ & 3.19 & $1.59-5.40$ & 5.90 & $2.97-10.19$ \\
\hline 75 & 0 & 0 & 21 & $17-25$ & 2.97 & $1.89-4.02$ & 3.33 & $2.48-4.72$ & 6.30 & $4.37-7.56$ \\
\hline 150 & 0 & $\mathbf{0}$ & 24 & $15-29$ & 3.12 & $0.90-5.14$ & 3.07 & $0.64-5.52$ & 6.19 & $1.54-10.66$ \\
\hline 0 & 150 & 0 & 25 & $11-44$ & 2.87 & $0.99-6.65$ & 3.44 & $1.29-7.36$ & 6.31 & 2.28-14.01 \\
\hline 75 & 150 & 0 & 34 & $28-40$ & 4.83 & $3.17-5.95$ & 5.29 & $2.52-7.91$ & 10.12 & $5.69-13.86$ \\
\hline 150 & 150 & $\mathbf{0}$ & 28 & $20-34$ & 3.87 & $1.76-5.55$ & 4.06 & $2.03-6.58$ & 7.93 & $3.79-12.13$ \\
\hline 0 & $\mathbf{0}$ & 300 & 30 & $24-37$ & 4.52 & $2.62-6.14$ & 4.32 & $3.11-6.52$ & 8.84 & $5.73-12.58$ \\
\hline 75 & 0 & 300 & 25 & $21-32$ & 2.56 & $1.27-3.67$ & 3.31 & $1.92-4.78$ & 5.87 & $2.19-8.35$ \\
\hline 150 & 0 & 300 & 32 & $26-39$ & 5.35 & $4.52-6.52$ & 5.49 & $3.85-7.29$ & 10.83 & $8.52-13.81$ \\
\hline 0 & 150 & 300 & 26 & $15-36$ & 3.05 & $1.45-4.55$ & 3.59 & $2.00-4.94$ & 6.64 & $3.45-9.49$ \\
\hline 75 & 150 & 300 & 34 & $20-48$ & 4.40 & $1.64-6.70$ & 5.04 & $2.34-7.76$ & 9.44 & $3.98-14.46$ \\
\hline 150 & 150 & 300 & 32 & $25-41$ & 3.99 & $3.00-5.34$ & 4.64 & $3.30-6.10$ & 8.62 & $6.30-10.37$ \\
\hline
\end{tabular}


Table 3-2. TYPHA FERTLIZATION STUDY ANALYSIS OF VARIANCE SUMMARY

\begin{tabular}{|c|c|c|c|c|c|}
\hline \multirow{2}{*}{$\begin{array}{l}\text { Main } \\
\text { Effectili }\end{array}$} & \multirow{2}{*}{$\underset{(\mathrm{kg} / \mathrm{ha})}{\text { Rate }}$} & \multirow{2}{*}{$\begin{array}{c}\text { Mean Shoot } \\
\text { Density } \\
\left(\text { per } \mathrm{m}^{2}\right)\end{array}$} & \multicolumn{3}{|c|}{$\begin{array}{c}\text { Mean Dry Weight } \\
(\mathrm{mt} / \mathrm{ha})\end{array}$} \\
\hline & & & Aboveground & Belowground & Total \\
\hline Nitrogen & 0 & 26 & 3.28 & 3.64 & 6.92 \\
\hline Nitrogen & 75 & 28 & 3.69 & 4.24 & 7.93 \\
\hline Nitrogen & 150 & 29 & 4.08 & 4.31 & 8.39 \\
\hline Phosphorus & 0 & $\left.{ }^{25}\right]_{*}$ & 3.54 & 3.78 & 7.32 \\
\hline Phosphorus & 150 & 30 & 3.83 & 4.34 & 8.18 \\
\hline Potassium & 0 & $267 *$ & 3.39 & $3.73]_{*}$ & 7.12 \\
\hline Potassium & 300 & $30\rfloor$ & 3.98 & $4.40]$ & 8.37 \\
\hline Combined & $150-150-300$ & 32 & 3.99 & 4.64 & 8.62 \\
\hline
\end{tabular}

* = Significant difference at $\alpha=0.05$ 
Partitioning of biomass into above- and belowground portions of the plant was unaffected by fertilizer treatment. The percent of total dry weight found in the aboveground portion averaged $47 \%$ overall.

In order to explain the large variability in yield which, for the most part, was unexplained by fertilizer treatment, several other factors affecting yield were analyzed. These factors and their relationship to yield are presented in Figure 3-1. An analysis of variance was run examining the effect of fertilizer treatment on the dependent variables affecting yield. The significance of the treatment and overall means of the difference variables are shown in Table 3-3. Relationships between these variables and yield, and other factors affecting yield, were examined using correlations.

Survival rate, as measured by the number of plants replanted in June or the densities in July, was on average quite low and highly variable. A strong correlation exists between the July density and both final density and final yield indicating that the factor or factors affecting survival rate also strongly influenced final yield. From Table $3-3$, it can be seen that an average of half the plants were replanted in each plot. It can also be seen that fertilizer treatment had no effect on the number replanted or the density in July. Correlations between water levels in each plot, the number replanted and the density in July showed no relationship. There is, however, reason to suspect that the planting stock used resulted in a low survival rate. The quality of the commercially obtained stock was highly variable in terms of size and number of viable buds and shoots. Also, yields from plots planted with this material in other experiments (see Section 4.0) were significantly lower than those from plots planted with other stock.

The effect of fertilizer treatment on density was previously mentioned. Both phosphorus and potassium applications resulted in a statistically significant $20 \%$ increase in shoot density (Table 3-2). Although final density is strongly correlated with yield in this experiment, it does not appear that this density increase resulted in statistically significant higher yields except, possibly, in the case of belowground dry weight which was significantly higher in plots where potassium was applied.

Fertilizer treatment had no effect on competitor dry weight. Competitor dry weights were relatively high compared with Typha yields which may be the result of the slow early development of the cattail plants. After the cattail plants began growing vigorously in mid-season, the spread of competitors appeared to be controlled.

Application of phosphorus and potassium significantly and, in some cases, dramatically increased tissue concentrations of these nutrients. In the case of potassium, aboveground concentrations increased from $7,020 \mathrm{ppm}$ to $16,900 \mathrm{ppm}$ and belowground concentrations increased from $12,500 \mathrm{ppm}$ to $18,800 \mathrm{ppm}$ with the application of $300 \mathrm{~kg} / \mathrm{ha}$ of potassium. Application of $150 \mathrm{~kg} / \mathrm{ha}$ of phosphorus resulted in increases of above and belowground concentration from $1,910 \mathrm{ppm}$ to $2,160 \mathrm{ppm}$ and $3,630 \mathrm{ppm}$ to $3,880 \mathrm{ppm}$ respectively. Nitrogen application did not result in increased tissue nitrogen concentrations which were statistically significant.

Although tissue phosphorus and potassium concentrations were increased by the application of fertilizer, there is either no correlation between concentration and yield or a negative correlation indicating that tissue nutrient concentration of phosphorus and potassium was not the limiting growth factor. Tissue nitrogen concentration also shows a negative correlation with yield. It appears based on tissue nutrient comparisons in Subsection 3.3 and soil results presented later in this Section that nutrient availability 


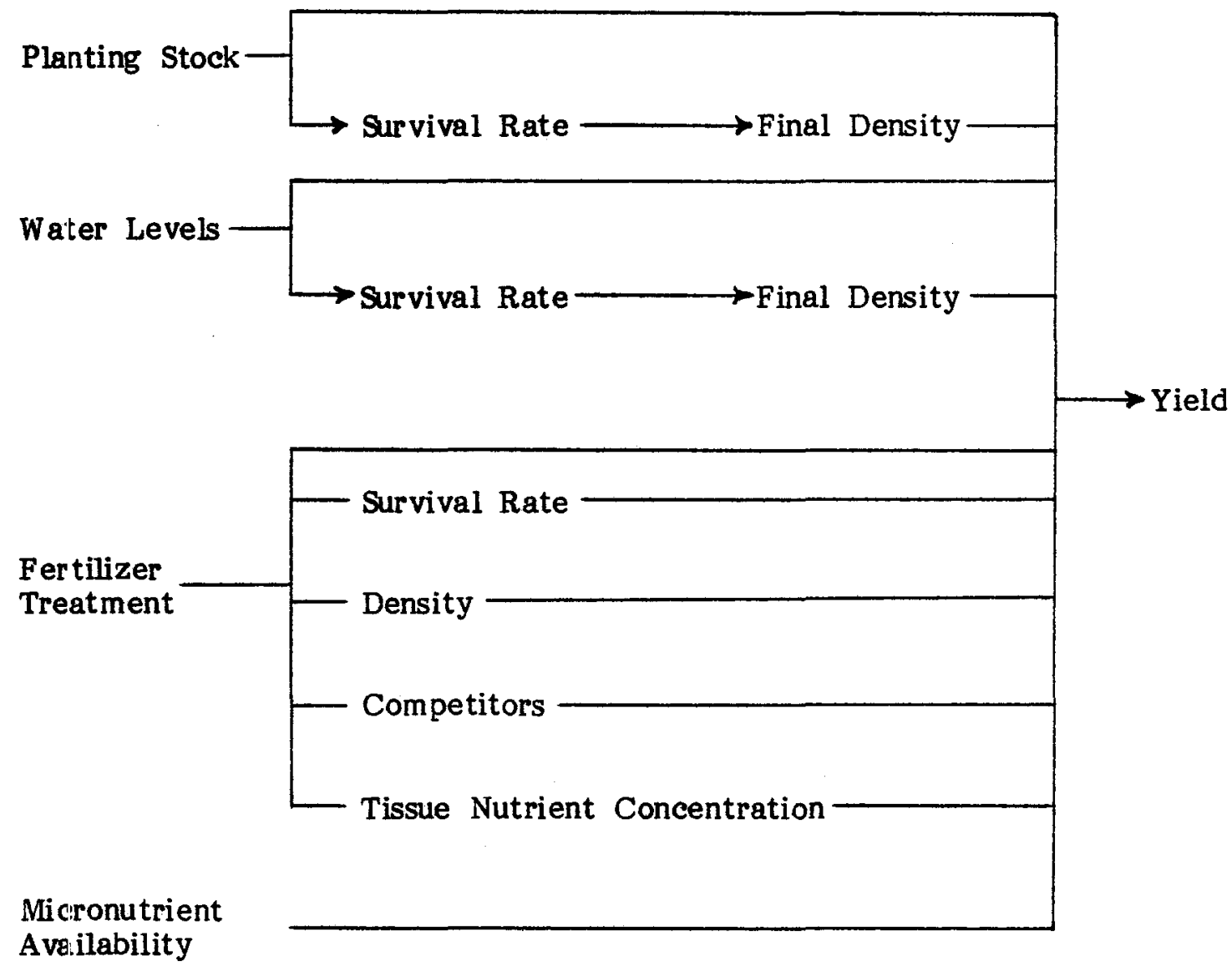

Figure 3-1. FACTORS AFFECTING FIRST SEASON YIELDS 
Table 3-3. SIGNIFICANCE OF FERTILIZER TREATMENT ON VARIABLES AFFECTING FINAL YIELD

Survival Rate and Density
Number Replanted
July Density
Final Density
Density Increase (July-October)
Competitors
Competitor Dry Weight
Tissue Nutrient Concentrations
Aboveground Nitrogen
Belowground Nitrogen
Aboveground Phosphorus
Belowground Phosphorus
Aboveground Potassium
Belowground Potassium
*Significant difference at $\alpha=0.05$
**Significant difference at $\alpha=0.01$
-No significant difference


was quite high to begin with in all plots, and applied fertilizer resulted in luxury consumption by the plants. This negated the effect of the treatment on yield in the first season, but may be extremely important in the second season since Typha is able to store nutrients in its rhizome system.

In order to ensure that micronutrients were not limiting in this experiment, they were applied to the field at the beginning of the season. Results of tissue micromutrient analysis indicate that these nutrients were not limiting (see Section 3.3), and results of correlations indicate no relationship between productivity and micronutrient concentration.

After examining these factors which may have influenced yield, it is difficult to explain the large variability in yield. Problems related to establishing the stand appear to have had the greatest impact on first season productivity.

In addition to the factors affecting first season productivity discussed above, other factors will affect second season yields. At the start of the second growing season, an established root system plus reserves of carbohydrates and nutrients in the rhizome system should result in rapid early season growth. Differences in nutrient reserves and nutrient availability attributed to first season fertilizer treatment could result in significantly higher yields in the second season.

Based on analysis of nutrient standing crop (defined as grams of nutrient per $\mathrm{m}^{2}$ ) and fall soil nutrient levels, it appears that the fertilizer treatment will carry over into the second season. Figure 3-2 shows the nutrient standing crop for nitrogen, phosphorus, and potassium at the end of the first growing season. With the exception of aboveground nitrogen amounts, all increases resulting from fertilizer treatment are statistically significant. Figure 3-3 shows the available phosphorus and potassium levels in the soil at the end of the first season. Fertilizer application resulted in statistically significant increases in soil fertility. Available soil nitrogen is currently being analyzed. Based on these results, it is reasonable to expect that second season yields and densities will be affected by the nutrient treatment.

\subsubsection{Conclusions}

While conclusions are difficult to arrive at for field experiments after only one year of research, the following tentative conchusions can be reached:

- Phosphorus and potassium applications resulted in increased density and potassium application resulted in increased belowground dry weight.

- Nutrients were not the limiting growth factor in the first season. High initial soil fertility and poor early season growth increased nutrient availability and decreased nutrient requirements, respectively.

- Fertilizer treatments were effective in significantly increasing tissue nutrient concentration, nutrient standing crop, and soil fertility for phosphorus and potassium and in some cases nitrogen.

- Increased nutrient standing crop and soil fertility attributed to fertilizer treatment should carry over into the second season and have an effect on yield and density. 


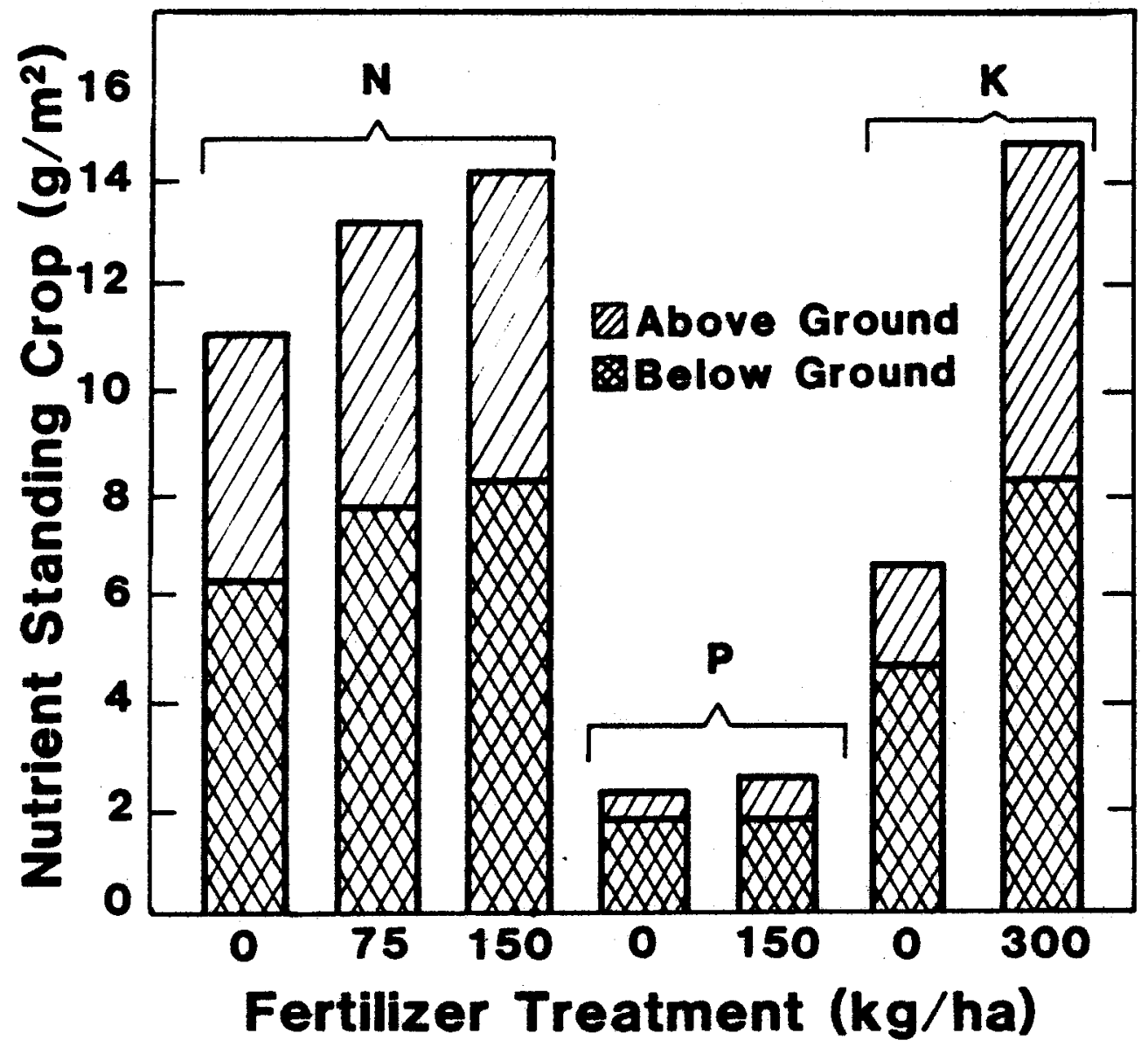

Figure 3-2. NUTRIENT STANDING CROP AT THE END OF THE FIRST GROWING SEASON 


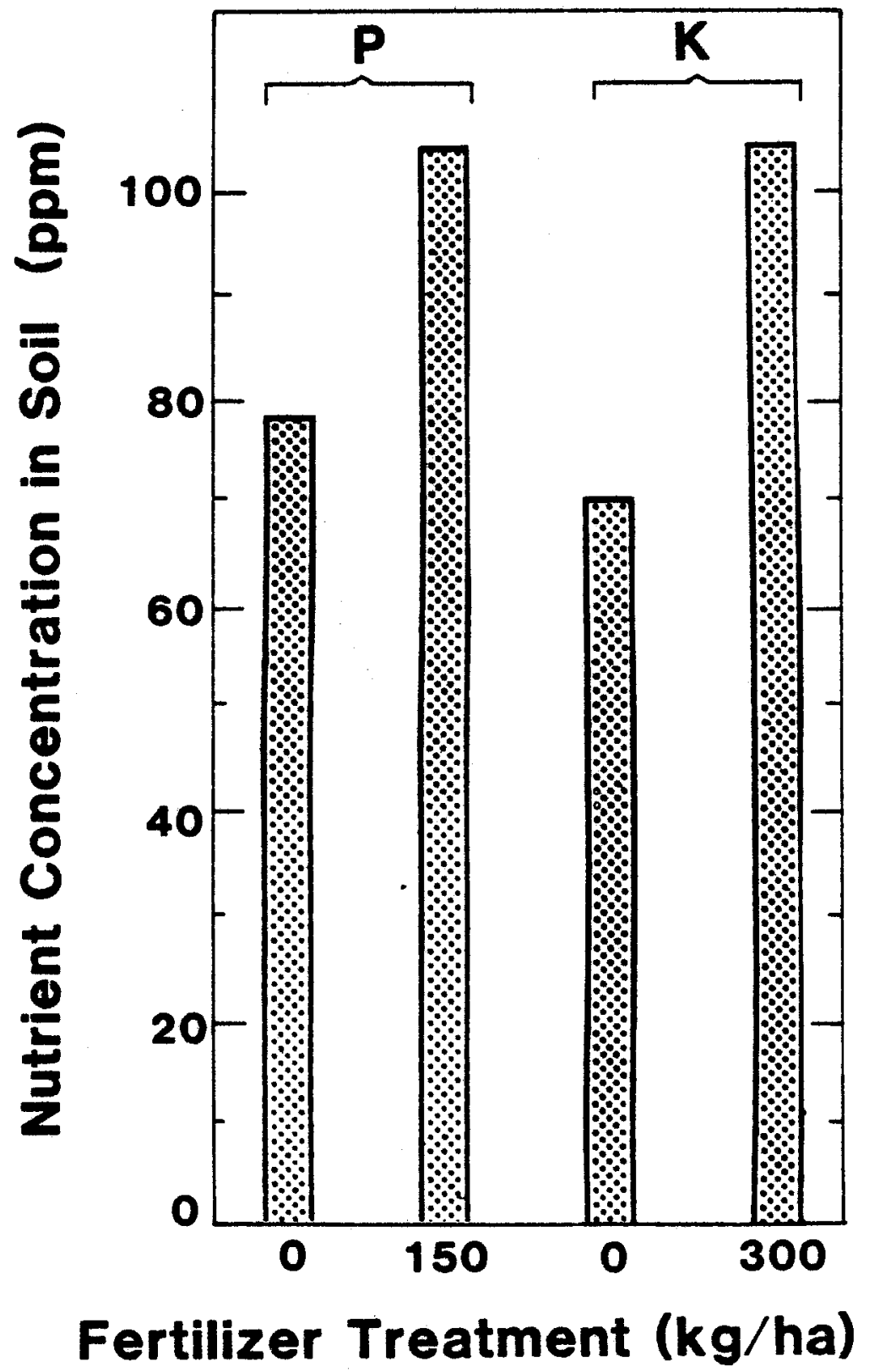

Figure 3-3. AVAILABLE SOIL PHOSPHORUS AND POTASSIUM LEVELS AT THE END OF THE FIRST GROWING SEASON 
- Factors affecting early season growth of new stands (especially quality of planting stock) appeared to have the greatest impact on first season biomass production. These factors were unrelated to fertilizer application.

- Because of 1) high nitrogen availability in newly cultivated organic soils, 2) nitrogen loss through denitrification, and 3) low early season nitrogen requirements, it may be more effective and less costly to apply nitrogen midway through the season and to apply it only if nutrient deficiencies are observed.

\subsection{NUTRIENT AND YIELD COMPARISONS}

\subsubsection{Objectives}

Little is known about the nutrient requirements of Typha or plant-nutrient relations in anaerobic organic soils. The objectives of this section are to:

- Compare yield and density with tissue nutrient concentration and soil fertility from a number of natural and established stands of Typha.

- Gain a better understanding of nutrient requirements of Typha and the relationship of yield and nutrients in plant tissue and soil.

\subsubsection{Methods}

Density, yield, and tissue element concentration data were gathered from three 1981 field experiments (see Sections 2.0 and 4.0), a 1980 experiment (6), and a 1978 survey of natural stands located in Minnesota (5). With noted exceptions, all information was gathered from experimental stands planted with rhizome pieces at a density of $9 / \mathrm{m}^{2}$ and fertilized at a rate of $75-150-300 \mathrm{~kg} / \mathrm{ha}$ of nitrogen, phosphorus, and potassium. Land preparation ranged from small paddies to a $1.5 \mathrm{~m}$ excavated peat site.

Tissue nitrogen analysis was done using a micro-Kjeldahl process. All other tissue nutrient concentrations were determined using an ICP analyzer at the University of Minnesota Research Analytical Laboratory. Soil nutrient analysis results represent Brays \#1 extractable phosphorus, exchangeable potassium, and total concentration for all other nutrients.

\subsubsection{Results and Discussion}

A comparison of density, yield, and the tissue macronutrient levels of nitrogen, phosphorus, and potassium is presented in Table 3-4. Considerable variability exists in density and yield between locations. Interestingly, there is no correlation between tissue macronutrient concentrations and either aboveground dry weight or density. In fact, the location with the highest above- and belowground yield, in $1.5 \mathrm{~m}^{2}$ paddies, also had the lowest aboveground nitrogen concentration (0.68\% of dry weight) and the mean belowground nitrogen concentration (0.99\% of dry weight). Excluding the natural stand survey, there is also no correlation between macronutrient tissue concentrations and 
Table 3-4. FIRST SEASON DENSITIES, YIELDS AND NUTRIENT LEVELS

FROM FIELD TRIALS IN 1980 AND 1981

AND FROM NATURAL STAND SURVEYS

\begin{tabular}{|c|c|c|c|c|c|c|c|c|c|c|c|c|c|}
\hline \multicolumn{2}{|c|}{ Location } & Soil Type & Land Preparation & $\begin{array}{l}\text { Density } \\
\text { (per } \mathrm{m}^{2} \text { ) }\end{array}$ & $\frac{\text { Dry }}{\text { TAG }}$ & \multicolumn{2}{|c|}{$\frac{\text { Weight } \frac{\left(\mathrm{g} / \mathrm{m}^{2}\right)}{\text { BG }}}{\text { TTL }}$} & $\begin{array}{l}\text { Tissue } \\
\text { AG }\end{array}$ & $\frac{N}{B G}$ & $\begin{array}{l}\text { Tissue } \\
\text { AG }\end{array}$ & $\frac{\mathrm{P}}{\mathrm{B}} \%$ & $\begin{array}{l}\text { Tissue } \\
\text { AG }\end{array}$ & $\frac{\mathrm{K}}{\mathrm{B}}{ }^{\%}$ \\
\hline A) & St. Paul & Organic Loam & Paddies & 51 & 885 & 1,052 & 1,937 & 0.68 & 0.99 & 0.11 & 0.29 & 1.42 & 1.65 \\
\hline B) & Aitkin & Organic Loam & Rotovated & 34 & 440 & 504 & 994 & 1.55 & 1.76 & 0.22 & 0.40 & 1.75 & 1.89 \\
\hline C) & $\mathrm{Zim}$ & Peat & Rotovated & 25 & 270 & 345 & 620 & 1.29 & 0.99 & 0.14 & 0.25 & 0.98 & 1.55 \\
\hline D) & Zim & Peat & $0.6 \mathrm{~m}$ Excavation & 33 & 400 & 520 & 920 & 0.94 & 0.62 & 0.12 & 0.23 & 1.72 & 1.79 \\
\hline E) & Zim & Peat & $1.5 \mathrm{~m}$ Excavation & 27 & 380 & 490 & 860 & 1.11 & 0.67 & 0.13 & 0.21 & 1.63 & 1.61 \\
\hline F) & $\operatorname{Zim}(1980)$ & Peat & Rotovated & 35 & 635 & 551 & 1,187 & 1.2 & 1.4 & 0.20 & 0.46 & 2.9 & 2.7 \\
\hline G) & $\operatorname{Zim}(1980)$ & Peat & $0.2 \mathrm{~m}$ Excavation & 40 & 292 & 625 & 916 & 0.8 & 0.7 & 0.11 & 0.34 & 1.4 & 2.1 \\
\hline H) & Minnesota & Natural Stand & ey $(1978)$ & 51 & 1,395 & - & - & 1.31 & - & 0.22 & - & 1.84 & - \\
\hline
\end{tabular}

$\mathrm{AG}=$ aboveground

$\mathrm{BG}=$ belowground

TTL = total

- Results in items $A-G$ above are means from plots planted with rhizome planting stock at $9 / \mathrm{m}^{2}$ (except $\mathrm{St}$. Paul $=16 / \mathrm{m}^{2}$ ) and sampled between late September and late October.

- Fertilizer in items A-G above was applied at the rate of $75-150-300 \mathrm{~kg} / \mathrm{ha}$ (except $\mathrm{Zim}, 1980=90-360-360$ ).

- Item $H$ above represents the mean results of mono-specific even-aged stands located throught Minnesota (5). Sampling time was late July and August. 
belowground dry weight. These results would indicate both the potential for high biomass yields with low nutrient inputs and the need for management practices designed to recuce luxury consumption of nutrients by Typha.

In all locations, the factor most closely correlated with both above-and belowground yield is density. This has also been shown to be the case in other experiments presented in this report (see Sections 2.0 and 4.0). While this result is not startling in itself, it poses many questions concerning the factors regulating or limiting density. In the context of this section's objectives, it does not appear that tissue nutrient concentrations of nitrogen, phosphorus, or potassium are among these factors. There is no statistically significant correlation between macronutrient tissue concentrations and density.

In an effort to better understand which nutrient other than nitrogen, phosphorus, or potassium could be affecting density or final biomass yield, results of elemental analyses of other plant nutrients were examined. A comparison of these tissue element concentrations is presented in Table 3-5. Correlations run between these nutrient concentrations, density, and yield showed a statistically significant positive relationship between 1) aboveground tissue calcium concentration and density, and 2) aboveground tissue boron concentration and aboveground dry weight. While these correlation coefficients do not establish cause and effect relationships, they do serve to isolate certain factors for further study. This is an important first step when working with a new, highly complex system.

In addition to calcium and boron, two other elements are of interest because of their unusually high concentrations in Typha. These are sodium and iron. Mean aboveground sodium concentration across all locations was $0.18 \%$, but it was not uncommon to observe sodium levels approaching $1 \%$ of dry weight in individual plots. Belowground tissue concentrations were nearly identical to aboveground concentrations. The significance of this is not known since sodium is not generally considered to be an essential plant nutrient, although in certain crops it has been shown to increase yields (8). Iron is of interest because of both its high concentration and the way it is partitioned in the plant. The belowground concentration of iron is generally an order of magnitude greater than the aboveground concentration and an order of magnitude greater than that commonly found in higher plants (8). Again, the significance of this is unknown at this time.

Table 3-6 presents information on the soils from each of the locations. All soils were highly organic in composition and acidic. With the exception of phosphorus and potassium, element concentrations represent total concentrations and not necessarily available concentrations.

\subsubsection{Conclusions}

- High biomass yields may be achievable with relatively low nutrient inputs under certain conditions.

- Management practices need to be developed which will optimize utilization of nutrients by the plant and reduce luxury consumption.

- Shoot density and yield are highly correlated. It appears that density increase following planting is one of the principal determinants of first season yields. While tissue nutrient concentrations at the levels reported in this section do not seem to affect this density increase, other factors 
Table 3-5. FIRST SEASON TISSUE ELEMENT CONCENTRATIONS FROM

FIELD TRIALS IN 1980 AND 1981

AND FROM NATURAL STAND SURVEYS

\begin{tabular}{|c|c|c|c|c|c|c|c|c|c|c|c|c|c|c|c|}
\hline \multirow{3}{*}{\multicolumn{2}{|c|}{ Location }} & \multicolumn{6}{|c|}{ \% Dry Weight } & \multicolumn{8}{|c|}{ Parts per Million } \\
\hline & & \multicolumn{2}{|c|}{ Calcium } & \multicolumn{2}{|c|}{ Magnesium } & \multicolumn{2}{|c|}{ Sodium } & \multicolumn{2}{|c|}{ Tron } & \multicolumn{2}{|c|}{ Manganese } & \multicolumn{2}{|c|}{ Copper } & \multirow{2}{*}{\multicolumn{2}{|c|}{$\begin{array}{l}\text { Boron } \\
\text { AG BG }\end{array}$}} \\
\hline & & AG & BG & $A G$ & $\mathbf{B G}$ & $\mathbf{A G}$ & BG & $\mathrm{AG}$ & BG & AG & BG & $\mathbf{A G}$ & $\mathbf{B G}$ & & \\
\hline A) & St. Paul & 1.24 & 0.66 & 0.14 & 0.21 & 0.17 & 0.15 & 141 & 725 & 500 & 218 & 2 & 5 & 12 & 6 \\
\hline B) & Aitkin & 1.11 & 0.61 & 0.16 & 0.22 & 0.36 & 0.25 & 218 & 3,205 & 500 & 218 & 3 & 5 & 15 & 8 \\
\hline C) & Zim & 0.90 & 0.49 & 0.24 & 0.23 & 0.22 & 0.25 & 40 & 1,186 & 497 & 165 & 3 & 4 & 10 & 7 \\
\hline D) & Zim & 0.79 & 0.48 & 0.15 & 0.19 & 0.09 & 0.13 & 35 & 1,146 & 595 & 229 & 3 & 4 & 9 & 7 \\
\hline E) & Zim & 0.87 & 0.49 & 0.17 & 0.19 & 0.14 & 0.17 & 41 & 973 & 506 & 191 & 3 & 2 & 11 & 7 \\
\hline F) & $\operatorname{Zim}(1980)$ & 1.0 & 0.5 & 0.19 & 0.23 & 0.03 & 0.05 & 100 & 700 & 900 & 500 & 3 & 4 & 17 & 7 \\
\hline G) & $\operatorname{Zim}(1980)$ & 1.1 & 0.4 & 0.17 & 0.15 & 0.01 & 0.06 & 100 & 1,200 & 800 & 200 & 9 & 4 & 14 & 4 \\
\hline H) & Minnesota & 1.19 & - & 0.31 & - & 0.41 & - & 54 & - & 423 & - & 2 & - & 25 & - \\
\hline
\end{tabular}

AG = aboveground

$\mathrm{BG}=$ belowground 
Table $3-6$. SOIL INFORMATION FROM FIELD TRIALS IN 1980 AND 1981

AND FROM NATURAL STAND SURVEYS

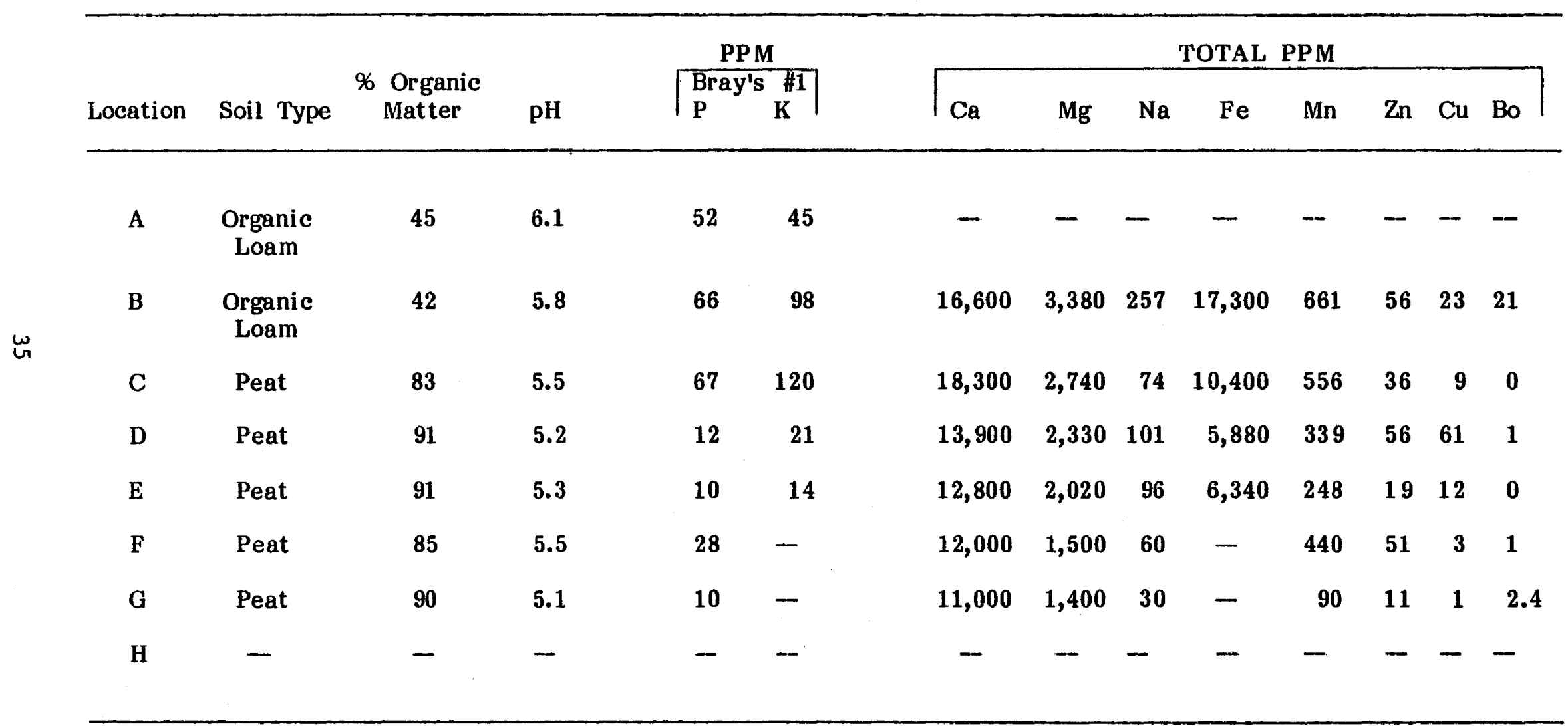

Note: With the exception of Location A, all samples were taken in the spring or fall prior to planting and fertilization. Location A represents soil samples taken in the fall during sampling. No soil results were available for the natural stand survey $(\mathbf{H})$. 
such as soil temperature, water levels, or initial planting density may. Further research is needed on factors regulating or limiting density increase.

- Results presented in this section begin to provide valuable baseline numbers which can be used for comparative purposes in future experiments.

- With one exception, first season yields from newly established managed stands are lower than those from established natural stands. This is an expected result. The one location with aboveground yields comparable to natural stands does, however, indicate the potential of increasing first season productivity. 
SECTION 4.0

WETLAND SPECIES COMPARISONS

AND MICROPROPAGATION

\subsection{INTRODUCTION}

Typha is only one of an array of productive wetland plants that may have potential as biomass crops. Through extensive literature surveys and sampling natural stands (9) throughout Minnesota, the following five species were identified for further sereening:

- Carex atherodes (sedge)

- Phragmites australis (reed)

- Scirpus fluviatilis (bulrush)

- Sparganium eurycarpum (bur reed)

- Spartina pectinata (cordgrass).

Although high yields from natural Typha stands throughout the world have been amply documented (6), it is also clear that yields vary considerably. Obviously such factors as latitude, nutrient and water availability, herbivore damage, competition, species, and genotype all contribute to this variation. In previous studies $(5,9)$, extensive surveys of natural Typha stands in Minnesota were carried out. Five of the most productive stands were selected for this study:

- Carlos Avery Wildlife Management Area, Minnesota

- Eagle Lake Wildlife Management Area, Minnesota

- Fort Snelling State Park, Minnesota

- Roseau Wildlife Management Area, Minnesota

- Syre, Minnesota .

The natural hybrid of Typha spp., Typha $\mathrm{x}$ glauca, appears to be more productive than either of the parental species, Typha latifolia or Typha angustifolia. Micropropagation offers the opportunity for rapid, large scale reproduction of selected clones, thus expediting bioenergy plantation establishment. Developing a method of establishing an untested species in tissue culture is often difficult and time-consuming, particularly with monocots. Factors influencing the micropropagation of Typha include:

- plant part used as explant

- disinfestation procedures

- $\quad \mathrm{pH}$ of medium

- light vs. dark

- temperature 


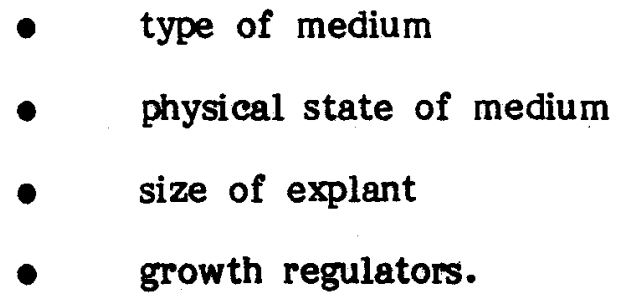

\subsection{WETLAND SPECIES AND TYPHA GENOTYPE COMPARISONS}

\subsubsection{Objectives}

The objective of both the wetland species comparison and the Typha genotype experiments was to compare productivity under identical growing conditions including such factors as plant density, above- and belowground dry weight and tissue nutrient content after one and two years of growth. The Typha experiment was terminated after the first season; the rhizomes will be planted at the Zim, Minnesota site to provide superior planting material for future studies. The wetland species experiment will be carried out for two seasons as originally planned. Demonstration plots of Phragmites, Scirpus, and Sparganium were also established on the excavated plots discussed in Section 2.0.

\subsubsection{Methods}

The wetland species and Typha genotype comparisons were each designed as $6 \times 6$ latin squares consisting of $36 \overline{1.5 \mathrm{~m}^{2}}$ paddies. Each paddy was filled with an organic loam and fertilized with $1250 \mathrm{~kg} / \mathrm{ha}$ of $6-12-24$. Vegetative planting material was collected from the productive natural stands identified from previous studies or purchased from Kester's Nursery. The paddies were planted May 12-13, 1981 at a planting rate of 25 rhizomes per paddy $\left(17 / \mathrm{m}^{2}\right)$. The first season sampling was carried out October $7-16$, 1981 for the aboveground portions and October 27 to November 3, 1981 for the belowground portions of the Typha experiment. No first season belowground sampling was carried out on the wetland species comparison experiment.

The demonstration plots of Phragmites, Scirpus, and Sparganium were planted at a rate of nine rhizomes $/ \mathrm{m}^{2}$; see Section 2.0 for further explanation of land preparation and water control. The above- and belowground material was harvested from one half of each plot during October; the remaining half of each plot will be sampled at the end of the 1982 growing season.

\subsubsection{Results and Discussion}

\subsubsection{Wetland Species Comparison}

Table 4-1 presents first season shoot density and aboveground dry weight. Species are ranked in descending order by aboveground dry weight. Scirpus fluviatilis (Scirpus II), planted with material collected at Fort Snelling State Park, attained the highest aboveground dry weight at 9.2 tons/hectare followed by Scirpus fluviatilis (Scirpus I) and Sparganium eurycarpum, $7.5 \mathrm{mt} / \mathrm{ha}$ and $6.0 \mathrm{mt} / \mathrm{ha}$ respectively, both of which were 
Table 4-1. WETLAND SPECIES COMPARISON: FIRST SEASON SHOOT DENSITY AND ABOVEGROUND DRY WEIGHT

\begin{tabular}{|c|c|c|c|c|c|}
\hline \multirow[t]{2}{*}{$\begin{array}{l}\text { Plant } \\
\text { Genus }\end{array}$} & \multicolumn{2}{|c|}{$\begin{array}{l}\text { Shoot Density } \\
\left(\text { per } \mathrm{m}^{2}\right)\end{array}$} & \multicolumn{3}{|c|}{$\begin{array}{l}\text { Aboveground Dry Weight } \\
\text { (mt/ha) }\end{array}$} \\
\hline & Mean & Range & Mean & & Range \\
\hline Scirpus (II) & 1477 & $122-172$ & 9.27 & & $7.8-10.2$ \\
\hline Seirpus (I) & 168 & $116-217$ & 7.5 & 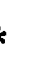 & $6.0-8.5$ \\
\hline Sparganium & 109 & $94-134$ & 6.0 & & $4.7-7.3$ \\
\hline Spartina & 80 & $67-106$ & 5.6 & * & $3.2-7.6$ \\
\hline Carex & 105 & $55-158$ & 4.4 & & $1.8-6.4$ \\
\hline Phragmites & $26]$ & $9-65$ & $0.57 *$ & & $0.1-1.3$ \\
\hline
\end{tabular}

*Homogeneous subgroups by HSD method (see text). 
planted with material purchased from a commercial nursery. Multivariate analysis of variance, using the University of Minnesota Computer Center's (UCC) SPSS version 8.3, indicates that differences among species in aboveground dry weight and density are significant at the $\mathbf{0 . 0 5}$ level. Tukey's Honestly Significant Difference (HSD) test which allows one to make comparisons between and among species was also used. The vertical lines on Table 4-1 represent homogeneaus subgroups; means joined by vertical lines do not significantly $(p=0.05)$ differ from one another. Thus Phragmites is significantly different in both dry weight and density from all other species while Sparganium, Spartina, and Carex form a coherent homogeneous subgroup in respect to both dry weight and density.

Results from the demonstration plots at Zim are presented in Table 4-2. No valid comparisons can be made among or between excavation depths or species since there is no replication. It is interesting to note, however, that Scirpus is again highest in dry weight with a mean of $10.5 \mathrm{mt} / \mathrm{ha}$ total dry weight followed by Sparganium at 8.8 $\mathrm{mt} / \mathrm{ha}$ and Phragmites at $0.7 \mathrm{mt} / \mathrm{ha}$. It is important to note the differences in the original planting rate between the paddies $\left(17 / \mathrm{m}^{2}\right)$ and the demonstration plots $\left(9 / \mathrm{m}^{2}\right)$. There is no clear pattern in relation to excavation depth.

In general, first season yields of Scirpus and Sparganium equal or exceed values reported for natural stands (Table 4-3). Yields of Carex and Spartina were somewhat lower. Second season results from managed paddies should be more comparable to natural stands.

First year results with Phragmites were disappointing. Aboveground yields in natural stands often exceed $10 \mathrm{mt} / \mathrm{ha}$. Initial establishment appears to be the most significant problem. Greenhouse and paddy trials will be carried out to determine optimal propagation and transplanting techniques.

\subsubsection{Typha Genotype Comparison}

Figures 4-1 and 4-2 present mean total dry weight and mean plant density by source of planting material. Multivariate analysis of variance by source of planting material reveals that while aboveground, belowground, and total dry weights are significantly different (0.05), plant densities are not. However, overall plant density and total dry weight are significantly correlated $(r=0.5, p=0.001)$. Use of Tukey's HSD results in the homogeneaus subgroups depicted in Table 4-4, where planting stock is ranked by total dry weight. Eagle Lake planting stock attained the highest first season total dry weight at $23.0 \mathrm{mt} / \mathrm{ha}$; next came Carlos Avery stock at $21.5 \mathrm{mt} / \mathrm{ha}$ and Roseau stock at 21.3 $\mathrm{mt} / \mathrm{ha}$. When net dry weight is considered (total dry weight minus dry weight of the original planting material), overall ranking remains the same and two overlapping subgroups result with the Syre stock appearing in both.

Table 4-5 presents tissue nutrient concentrations for selected macro- and micronutrients. One-way analysis of variance indicates that differences are significant only for aboveground magnesium, sodium, and copper concentrations. See Section 3.0 for further comparisons.

Kester's stock ranks lowest in total yield and density. This material was purchased from Kester's Nursery; rhizomes were generally much smaller than those collected from natural stands and the dry weight of the initial planting material was significantly lower than that of the other planting stocks. 
Table 4-2. WETLAND SPECIES COMPARISON: DEMONSTRATION PLOTS

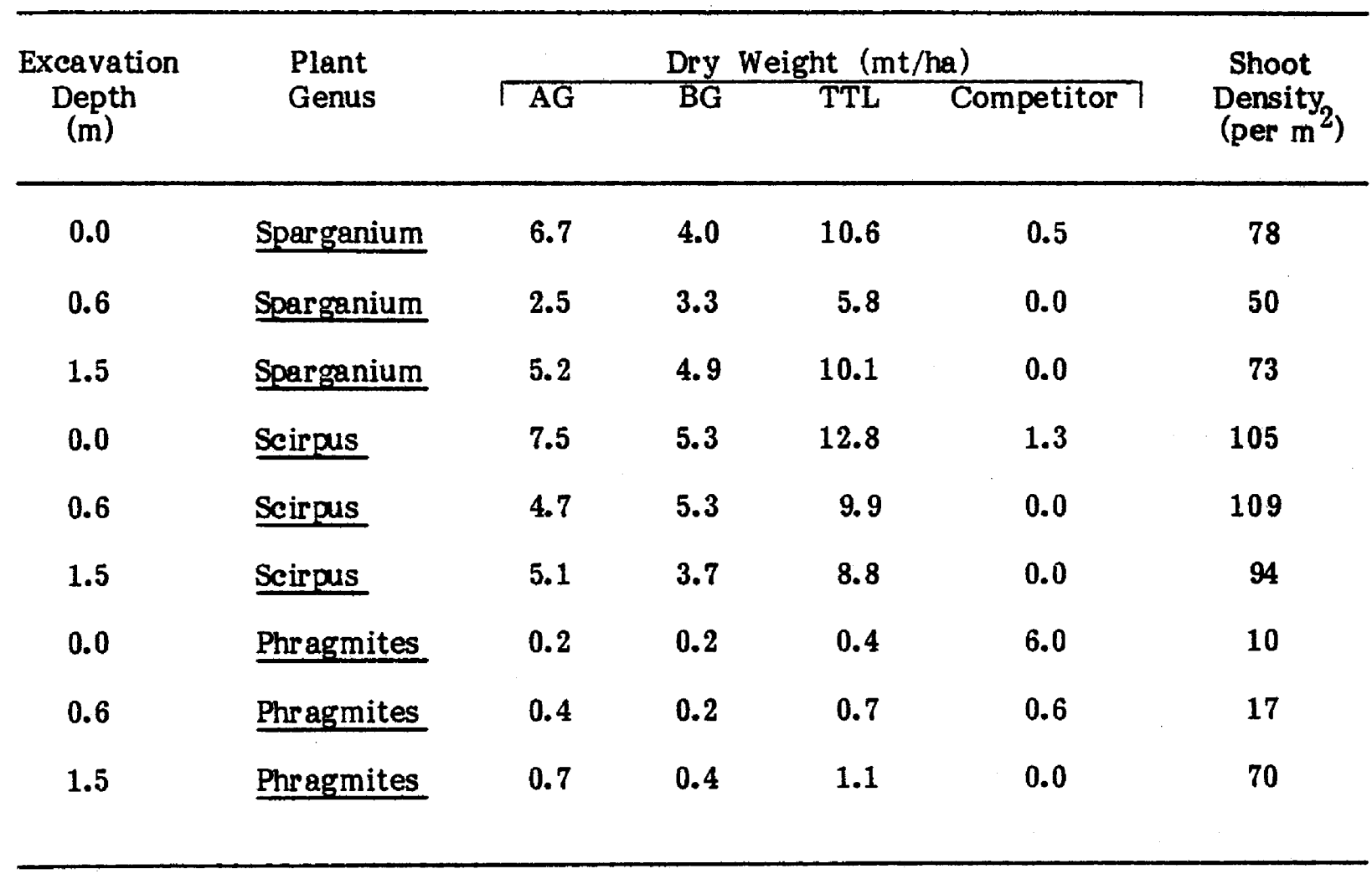

$A G=$ aboveground

$\mathrm{BG}=$ belowground

TTL $=$ total 
Table 4-3. SUMMARY OF WETLAND SPECIES STANDING CROP IN NATURAL STANDS

\begin{tabular}{|c|c|c|c|}
\hline Species & $\begin{array}{l}\text { Dry Weight } \\
\text { (mt/ha) } \\
\text { Aboveground }\end{array}$ & Location & Reference \\
\hline \multirow[t]{4}{*}{ Carex atherodes } & 10.6 & Minnesota & (10) \\
\hline & 22.3 & Iowa & (11) \\
\hline & 8.5 & Iowa & (11) \\
\hline & 8.1 & Minnesota & (9) \\
\hline \multirow[t]{2}{*}{ Phragmites australis } & 11.0 & Iowa & (12) \\
\hline & 11.8 & Minnesota & (9) \\
\hline \multirow[t]{4}{*}{ Scirpus fluviatilis } & 9.8 & Wisconsin & (13) \\
\hline & 4.5 & lowa & (12) \\
\hline & 7.9 & Iowa & (11) \\
\hline & 5.9 & Minnesota & (9) \\
\hline \multirow[t]{3}{*}{ Sparganium eurycarpum } & 10.5 & Iowa & (11) \\
\hline & 7.7 & Iowa & (12) \\
\hline & 5.9 & Minnesota & (9) \\
\hline Spartina pectinata & 5.9 & Minnesota & (9) \\
\hline Spectina, Carex (mixed) & 11.6 & Minnesota & (9) \\
\hline
\end{tabular}




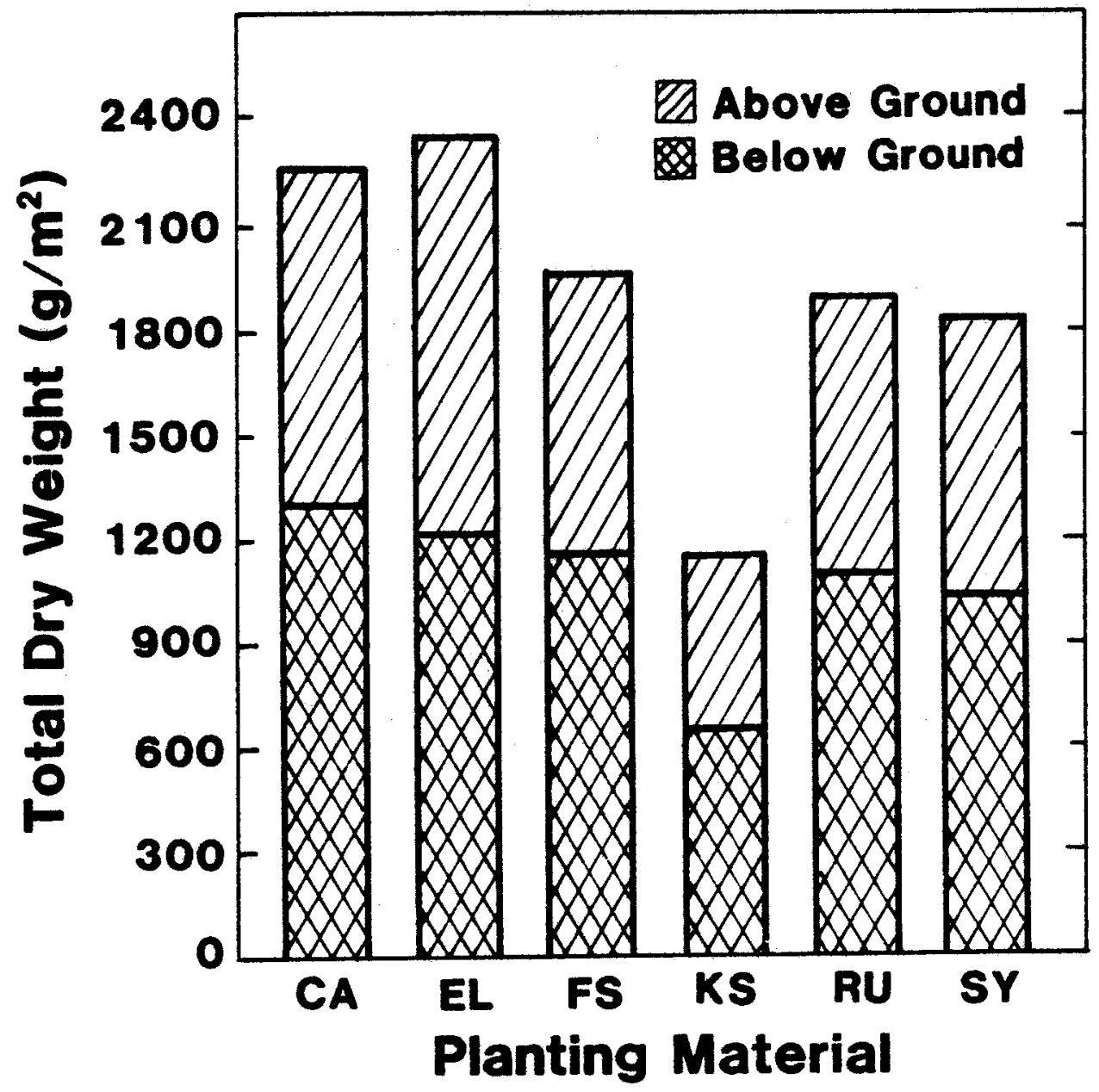
CA Carlos Avery WMA,MN
EL Eagle Lake WMA, MN
FS Fort Snelling SP, MN
KS Kester's Nurseries, WI
RU Roseau WMA, MN
SY Syre, MN

Figure 4-1. TYPHA SPP. GENOTYPE COMPARISON: ABOVE- AND BELOWGROUND DRY WEIGHT 


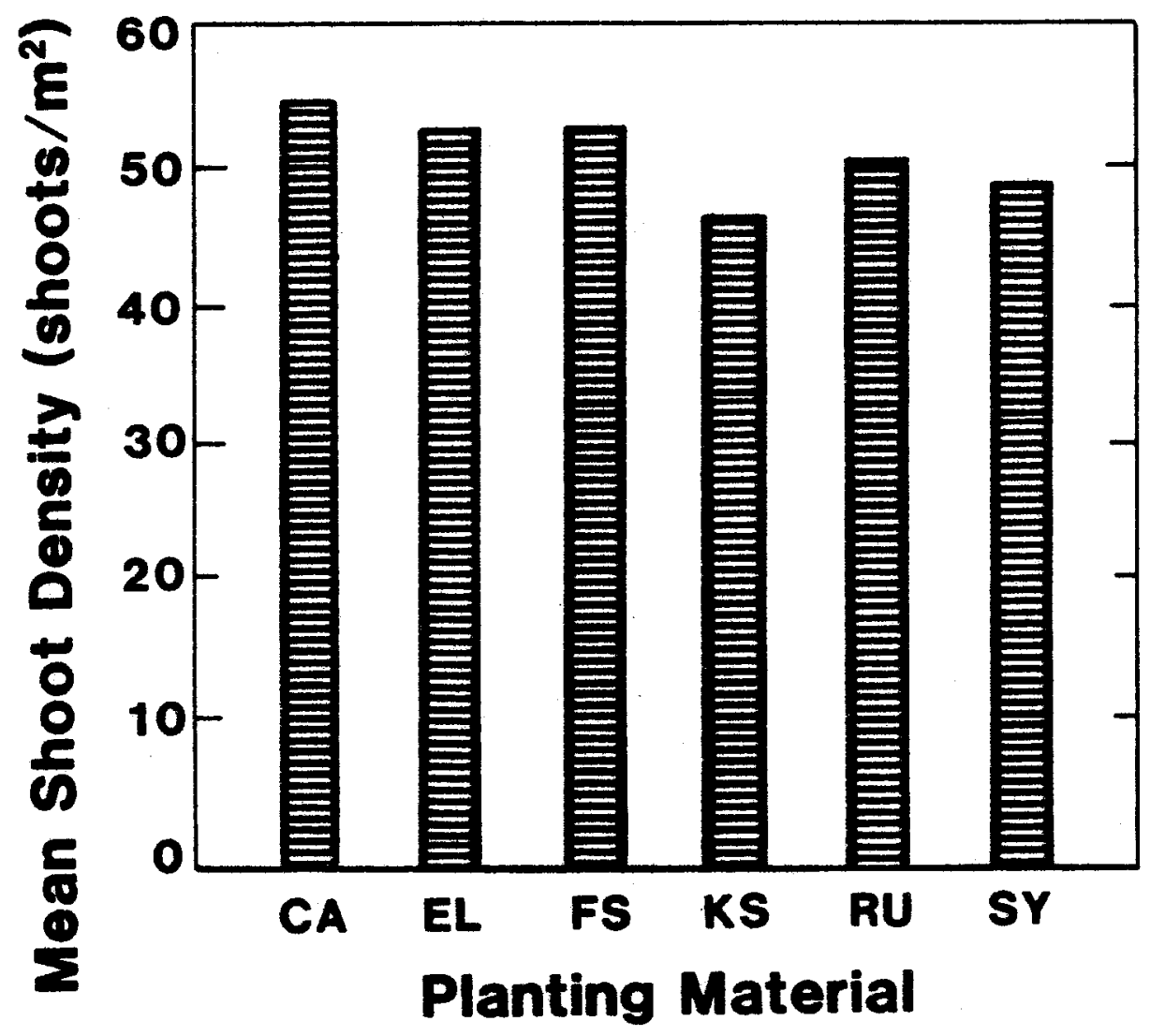

CA Carlos Avery WMA,MN

EL Eagle Lake WMA, MN

FS Fort Snelling SP, MN

KS Kester's Nurseries,WI

RU Roseau WMA, MN

SY Syre, MN

Figure 4-2. TYPHA SPP. GENOTYPE COMPARISON:

SHOOT DENSITY 
Table 4-4. TYPHA PLANTING STOCK COMPARISON

Source of

Planting Stock

$\frac{\text { Dry Weight }(\mathrm{mt} / \mathrm{ha})}{\mathrm{AG}}$ Total NG $\quad \begin{gathered}\text { Shoot Density } \\ \left(\text { per } \mathrm{m}^{2}\right)\end{gathered}$

(1) Eagle Lake

$\left.\left.\begin{array}{c}11.4 \pm 0.6] * \\ 9.7 \pm 0.9 \\ 9.2 \pm 0.9 \\ 8.6 \pm 0.8 \\ 8.3 \pm 0.5\end{array}\right] * \begin{array}{r}11.6 \pm 1.7 \\ 11.8 \pm 2.6 \\ 12.1 \pm 1.5 \\ 10.7 \pm 1.7 \\ 5.9 \pm 1.4] * \\ 9.7 \pm 4.4\end{array}\right] *$

$\left.\left.\begin{array}{c}23.0 \pm 1.7 \\ 21.5 \pm 3.1 \\ 21.3 \pm 2.3 \\ 19.3 \pm 2.2 \\ 18.0 \pm 4.8\end{array}\right] * \begin{array}{r}22.0 \pm 1.7 \\ 20.5 \pm 3.1 \\ 20.0 \pm 2.3 \\ 17.6 \pm 2.2 \\ 13.1+4.4\end{array}\right] *$

$\left.\begin{array}{l}51.0 \pm 5.9 \\ 53.0 \pm 7.4 \\ 51.0 \pm 4.3 \\ 49.0 \pm 7.4 \\ 53.0 \pm 7.7 \\ 46.0 \pm 8.9\end{array}\right]$ *

(7) Entire Population

(2) Carlos Avery

(3) Roseau

(4) Syre

(5) Fort Snelling

(6) Kester

$8.8+1.9 \quad 10.5 \pm 3.0$

$19.4 \pm 4.5 \quad 18.4+4.3$

$51.0+7.0$

AG = aboveground

$\mathrm{BG}$ = belowground

*Homogeneous subgroups by HSD method (see text). 
Table 4-5. TYPHA GENOTYPE COMPARISON

TISSUE NUTRIENT CONCENTRATIONS AT FINAL HARVEST*

\begin{tabular}{|c|c|c|c|c|c|c|c|c|c|c|c|c|c|c|c|c|c|c|c|c|}
\hline \multirow{3}{*}{$\begin{array}{l}\text { Planting } \\
\text { Stock } \\
\text { Source }\end{array}$} & \multicolumn{12}{|c|}{$\%$ of Dry Weight } & \multicolumn{8}{|c|}{ Parts per million } \\
\hline & \multicolumn{2}{|l|}{$\mathrm{N}$} & \multicolumn{2}{|c|}{$\overline{\mathbf{P}}$} & \multicolumn{2}{|c|}{$\mathbf{K}$} & \multicolumn{2}{|c|}{$\mathrm{Ca}$} & \multirow{2}{*}{\multicolumn{2}{|c|}{$\begin{array}{c}\overline{M g} \\
\mathrm{AG}^{* *} \mathrm{BG}\end{array}$}} & \multirow{2}{*}{\multicolumn{2}{|c|}{$\frac{\mathrm{Na}}{\mathrm{AG}^{* *} \mathrm{BG}}$}} & \multicolumn{2}{|c|}{$\mathrm{Fe}$} & \multicolumn{2}{|c|}{ Mn } & \multirow{2}{*}{\multicolumn{2}{|c|}{$\frac{\mathrm{Cu}}{\mathrm{AG}^{* *} \mathrm{BG}}$}} & \multicolumn{2}{|c|}{ Bo } \\
\hline & $\mathbf{A G}$ & BG & $\mathbf{A G}$ & BG & $\mathbf{A G}$ & BG & AG & BG & & & & & AG & BG & $\mathbf{A G}$ & BG & & & $\mathbf{A G}$ & BG \\
\hline (1) & 0.50 & 0.85 & 0.07 & 0.28 & 0.99 & 1.47 & 1.29 & 0.58 & 0.15 & 0.21 & 0.16 & 0.11 & 71 & 548 & 549 & 238 & 2 & 4 & 14 & 6 \\
\hline (2) & 0.63 & 1.01 & 0.10 & 0.29 & 1.38 & 1.60 & 1.36 & 0.63 & 0.16 & 0.21 & 0.08 & 0.14 & 71 & 793 & 657 & 261 & 2 & 6 & 14 & 7 \\
\hline (3) & 0.78 & 0.90 & 0.10 & 0.27 & 1.31 & 1.62 & 1.31 & 0.68 & 0.11 & 0.21 & 0.16 & 0.16 & 88 & 728 & 529 & 225 & 3 & 4 & 15 & 6 \\
\hline (4) & 0.58 & 1.02 & 0.16 & 0.28 & 1.33 & 2.80 & 1.00 & 0.64 & 0.17 & 0.20 & 0.17 & 0.16 & 472 & 710 & 388 & 208 & 4 & 4 & 8 & 6 \\
\hline (5) & 0.61 & $1.00^{\circ}$ & 0.08 & 0.28 & 1.50 & 1.72 & 1.22 & 0.68 & 0.11 & 0.21 & 0.26 & 0.17 & 57 & 824 & 425 & 190 & 1 & 8 & 12 & 6 \\
\hline (6) & 0.98 & 1.14 & 0.15 & 0.34 & 1.94 & 1.83 & 1.25 & 0.76 & 0.11 & 0.21 & 0.18 & 0.16 & 88 & 746 & 452 & 188 & 2 & 4 & 12 & 6 \\
\hline (7) & 0.68 & 0.99 & 0.11 & 0.29 & 1.42 & 1.65 & 1.24 & 0.66 & 0.14 & 0.21 & 0.17 & 0.15 & 141 & 725 & 500 & 218 & 2 & 5 & 12 & 6 \\
\hline
\end{tabular}

$\mathrm{AG}=$ aboveground

$\mathrm{BG}=$ belowground

Note: Planting stock sources are (1) Eagle Lake Wildlife Management Area, (2) Carlos Avery Wildlife Management Area, (3) Roseau, MN, (4) Syre, MN, (5) Fort Snelling State Park, (6) Kester's Nursery, (7) Entire Population.

* October, 1981

**Significant difference $\mathrm{p}=0.05$ 
Table 4-6 presents yields from the five natural stands selected for this study. In general, aboveground yields from the paddies are well within the range found in the natural stands. Unfortunately, little data are available on belowground yields from natural stands. Because Typha is a perennial, the rhizome component represents more than one season's productivity, thus first year results are not comparable to those from managed stands.

\subsubsection{Conclusions}

- First year results indicate that Scirpus, Sparganium, and Spartina grew successfully in managed paddies attaining yields comparable to and often exceeding those found in natural stands.

- Phragmites performed very poorly; initial establishment appears to be the primary problem. Further studies will be initiated to improve propagation and transplanting techniques.

- First year mean yield from planting stock obtained from productive natural stands of Typha was $20.6 \mathrm{mt} / \mathrm{ha}$ total dry weight. Aboveground dry weights were comparable to those found in the corresponding natural stands.

- Eagle Lake, Carlos Avery, and Roseau planting stock resulted in the highest yields while Kester's stock, obtained from a commercial nursery, ranked lowest in all categories.

- Typha spp. rhizomes from this study will be planted at the Zim site to provide planting material for future experiments.

- Micropropagation studies will focus on the most productive clones: Eagle Lake, Carlos Avery, and Roseau.

\subsection{MICROPROPAGATION OF TYPHA SPP.}

\subsubsection{Objectives}

- Establishment of Typha explants in tissue culture.

- Regeneration of plantlets through shoot proliferation and/or callus redifferentiation.

- Establishment of tissue-culture plantlets in conventional medium in field conditions.

\subsubsection{Methods and Results}

\subsubsection{Establishment of Typha Explants in Tissue Culture}

Plant Part Used as Explant. Initial experiments were designed to determine which plant part(s) would make the best explant material. These experiments were inconclusive 
Table 4-6. TYPHA SPP. YIELDS FROM SELECTED NATURAL STANDS IN MINNESOTA

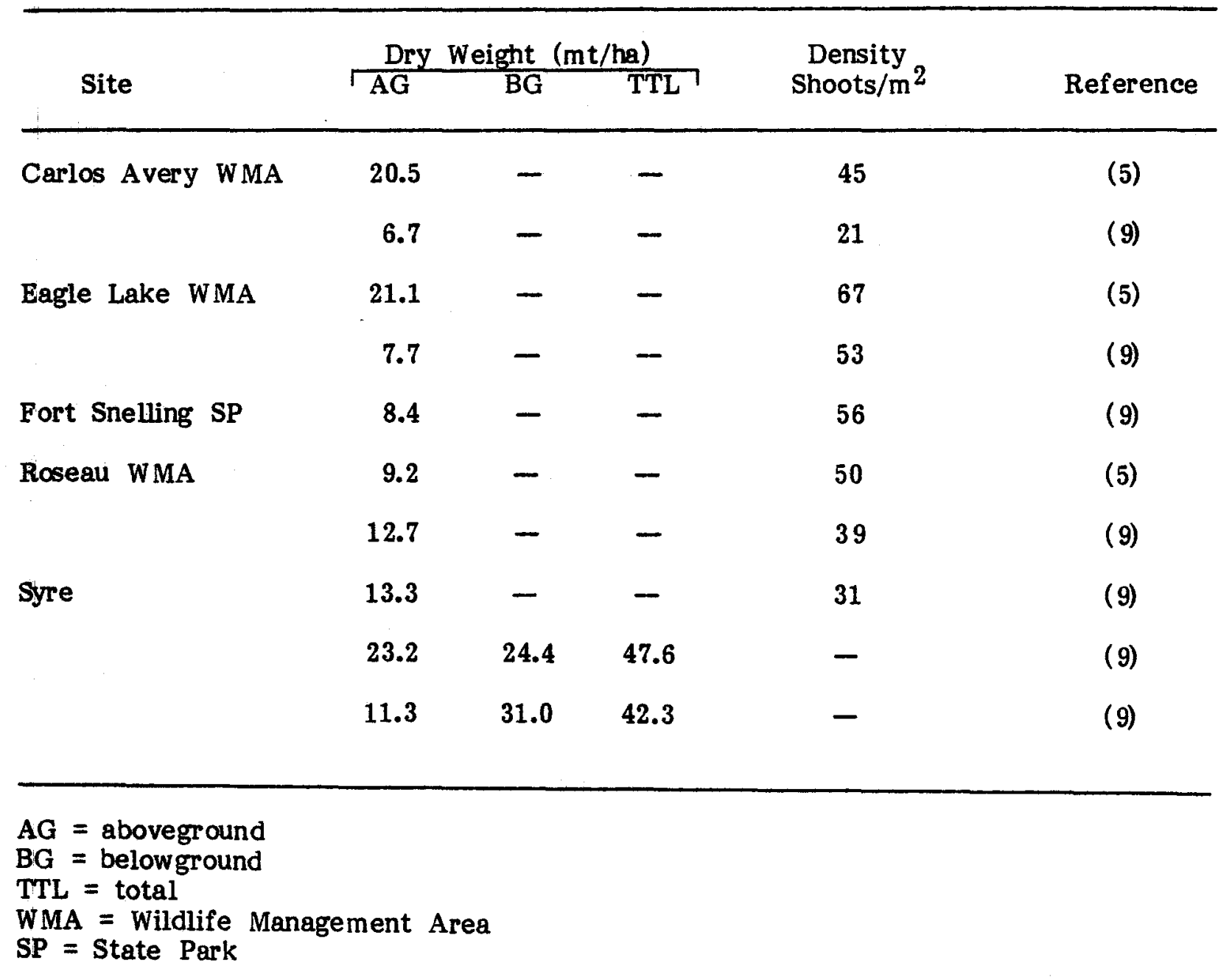


due to $100 \%$ contamination of rhizome slices and buds and an average of $25 \%$ contamination of explants from roots and leaf segments. None of these plant parts (rhizome, small buds, roots, or leaf segments) proved suitable as explant material.

In further experiments, segments of immature flower scapes were successfully cultured and produced callus. In one case, plantlets were regenerated from this callus.

Apical meristems with subtending leaf primordia have also proved to be a reliable source of explants with good viability and a contamination rate of $10 \%$ or less. By varying the concentration and type of growth regulators used, either single shoots or callus may be obtained from the apical meristem explants. Multiple shoots have not yet been produced, nor have plantlets been regenerated from this callus tissue.

Attempts to Reduce Contamination. Due to the massive contamination associated with attempted culture of roots, rhizomes, and leaves, a method was sought to reduce bacterial and fungal growth without affecting the growth of the explant.

$\mathrm{NaOCl}$ dips varying in concentration from $1.0 \%$ to $5.0 \%$ and in length from one minute to five minutes did not reduce the contamination rate. Those explants receiving the longer, more concentrated dips were usually killed by the treatment. The best results were achieved with $1 \% \mathrm{NaOCl}$ for one minute, which resulted in $22 \%$ explants alive and uncontaminated. Since these concentrations and durations of $\mathrm{NaOCl}$ should have eliminated surface contaminants it is likely that internal microflora account for the persistent contamination.

Alteration of $\mathrm{pH}$ of the Medium. Since Typha is known to be tolerant of a fairly low $\mathrm{pH}$, whereas bacteria are not, a pH level was sought at which bacteria would be inhibited, but Typha explants would survive. It was found that both bacteria and Typha would survive at $\mathrm{pH} 4.0$ and above, but neither did well below $\mathrm{pH}$ 4.0.

Temperature. Because the optimal temperature for growth of Typha in natural stands is $30^{\circ} \mathrm{C}$, some explants were maintained at a $32^{\circ} \mathrm{C}$ day $/ 26^{\circ} \mathrm{C}$ night temperature to see whether viability and growth rate would be enhanced. It was found that culture at high temperatures was not beneficial.

Type of Medium. The following media were all used in early experiments but their differential effects were not observable because of the contamination and poor viability of these cultures:

- Mur ashige and Skoog (14)

- Linsmaier and Skoog (15)

- Zimmermann (full and half strength) (16)

- Economov and Read (17).

Linsmaier and Skoog (LS) medium has been used in all recent experiments with satisfactory results. Other media will be tried again. 
Condition of Medium. In the early experiments, medium solidified with agar was used. Uncontaminated explants tended to become dry and brown after approximately 10 days; consequently, a trial was made of liquid medium. Explants were placed above the liquid medium on filter paper bridges. This procedure delayed the browning, although for some explants the condition still occurred after approximately three weeks.

Next, two experiments were conducted in which matched sets of explants were separated and half were placed on filter paper bridges while their partners were placed in liquid medium on the gyrotatory shaker. Explants on the shaker had the same viability rate, but they were a bit larger with broader, "fleshier," less turgid leaves. Their color was also a lighter green than shoots produced in the stationary filter paper bridges. Those on the shaker did not become brown and dry, but they were less hardy when transferred to conventional medium.

Apical Meristems: Size of Explant. Apical meristems with associated leaf primordia have been the most successful explant material used. They are readily obtained from stock plants maintained in hydroponics in the greenhouse. There is a low contamination rate (approximately 10\%) and good viability when appropriate growth regulators are provided. In two experiments, explants of various sizes from $0.5 \mathrm{~mm}^{3}$ to $3.0 \mathrm{~mm}^{3}$ were compared to determine the optimum size relative to contamination, viability, and ease of handling. The best size was found to be $2.0 \mathrm{~mm}^{3}$.

Method of Establishing Typha Explants in Tissue Culture. Sections of immature scapes and apical meristems with associated leaf primordia are the two explant materials which have been successfully cultured.

The method developed for disinfesting and establishing apical meristems in culture is as follows: A week before the explants are to be used, buds and small shoots are collected from stock plants, washed thoroughly with water, and stripped of any dead leaves or roots. They are placed in clean water in a high humidity growth chamber where they grow luxuriantly. On the day of the experiment, they are washed again, the roots and outer leaves removed, and leaves clipped to $1.0 \mathrm{~cm}$ length. These pieces are agitated for 10 minutes in a bath of $0.5 \% \mathrm{NaOCl}$ plus Tween 20 and then washed for 15 minutes under running tap water. Using the dissecting microscope under the laminar flow hood, the explants are recut to their final size, approximately $2.0 \mathrm{~mm}^{3}$. Finally, the explant is given a 20 second treatment in $1.0 \% \mathrm{NaOCl}$ with Tween 20 , rinsed in sterile water and placed in the culture flask.

The explants are grown on liquid Linsmaier and Skoog medium at room temperature $\left(25+1^{\circ} \mathrm{C}\right)$. The $\mathrm{pH}$ is 5.8 . They are grown either on filter paper bridges or on the gyrotatory shaker under a 16 hours light/8 hours dark photoperiod.

\subsubsection{Regeneration of Plantlets}

Regeneration of plantlets in tissue culture depends on their treatment with plant growth regulators. By varying the concentrations of these regulators, either shoots or callus may be induced.

In early experiments, the following growth regulators were tried, singly and in combinations, at various concentrations: naphthaleneacetic acid, benzyladenine, 2isopentenyladenine, and 2,4-D. Their effects were not observed, however, because of 
the massive contamination and poor viability of the cultures. In six recent experiments using 264 apical meristem explants on LS medium, the effects of one eytokinen (Zeatin) and one auxin $(2,4-D)$ were explored in detail.

Of the combinations of plant growth regulators tested thus far, the best growth of shoots results from no auxin and from 0.4 to $10 \mathrm{mg} / 1$ Zeatin. Whether or not roots have been formed in culture, the plantlets will root and survive when placed in conventional medium in a high humidity box. In no case did more than one plantlet form from one apical meristem. Unless multiple plantlets can be produced from some different combination of growth regulators, this does not appear to be a suitable method for large scale Typha propagation.

The best callus development occurs when apical meristems are cultured in medium containing 2.5 or $4.0 \mathrm{mg} / 12,4-\mathrm{D}$ and between 0.04 and $2.5 \mathrm{mg} / 1$ Zeatin. In cultures of immature flower scapes, $2.5 \mathrm{mg} / 1$ 2,4-D followed by 0.5 or $1.5 \mathrm{mg} / 1$ benzyladenine also produced callus which later regenerated into plantlets. So far, none of the callus from apical meristems has regenerated into plantlets though this is being attempted by varying the levels of growth regulators. Further work will be done to determine the best conditions for callus generation and redifferentiation. This route, though indirect, appears to be the most likely one for rapid Typha micropropagation.

\subsubsection{Establishment of Tissue-Cultured Plantlets in Conventional Medium in Field Conditions}

Shoots which have grown in culture vessels will root readily when transplanted to peat pots under high humidity conditions. When roots are well established (7-10 days), they may be moved to greenhouse conditions where they continue to grow well. No problems are anticipated in establishing these plantlets under field conditions.

\subsubsection{Conclusions}

- A method of establishing Typha explants in tissue culture has been formulated.

- The use of apical meristems with associated leaf primordia resulted in low contamination rates and good viability. The optimal explant size appears to be $2.0 \mathrm{~mm}^{3}$. These apical meristems will produce either callus or single shoots when treated with appropriate concentrations of growth regulators.

- Callus has been produced in culture and, in one case, callus from an immature scape regenerated plantlets.

- Plants grown in tissue culture have been successfully established in a conventional medium and transplanted to the greenhouse.

- Further work to determine the best conditions for callus generation and redifferentiation will be carried out. 


\section{SECTION 5.0}

\section{FUTURE RESEARCH}

The primary goal of this program is to develop Typha spp. (cattail) cultivation and management practices which maximize sustained yield while minimizing energy inputs and environmental degradation. A secondary goal is the evaluation of the biomass energy potential of other emergent aquatic plants. During the next funding period, work will focus on the following four areas:

$$
\begin{aligned}
& \text { - } \quad \text { stand management research } \\
& \text { - } \quad \text { relevant emergent plant technologies survey } \\
& \text { - } \quad \text { management options evaluation. }
\end{aligned}
$$

Stand management research will be continued and expanded. Plots established in 1981 will continue to be monitored for density, yield, and nutrient content. Further, new stands will be established in 1982 and monitored in the same manner. Plant density, yield, mutrient uptake, weed, and pest problems will be evaluated on these experimental plots during the 1982 and 1983 growing seasons.

Rhizome harvest studies will encompass defining conditions under which harvesting equipment must operate, establishing a feasible harvesting process, and developing equipment designs and cost factors based on evaluation of the overall harvesting scenario and comparisons to similar agricultural operations.

In order to best evaluate the potential of various emergent aquatic plants for bioenergy production, a literature search of management and harvest technologies will be conducted. When appropriate, site visits will be made to research institutions and commercial biomass operations.

Upon completion of these studies, an overall management options evaluation will be addressed. This evaluation will take the form of examining the practical and technical advantages and disadvantages of the various management options and formulating scenarios for biomass production in newly established Typha stands, natural Typha stands, reclaimed lands following peat mining, and stands used for wastewater treatment. 


\section{REFERENCES}

1. Westlake, D.F. 1963. Comparisons of Plant Productivity. Biol. Rev., 38, pp. 385-425.

2. Andrews, N.J. and D.C. Pratt. 1978. The Potential of Cattails (Typha spp.) as an Energy Source: Productivity in Managed Stands. J. Minn. Acad. Sci.., 44, pp. $5-8$.

3. Pratt, D.C., N.J. Andrews, R.L. Glass and R.E. Lovrien. 1981. Production of Wetland Energy Crops in Minnesota. Proceedings of Biomass Workshop, Midwest Universities Energy Consortium. pp. 158-175.

4. Moss, D.N. 1977. Improvement of Plant Photosynthesis Through Genetic Engineering. Symposium Papers, Clean Fuels from Biomass and Wastes, Institute of Gas Technology, pp. 63-71.

5. Pratt, D.C., V. Bonnewell, N.J. Andrews and J.H. Kim. 1980. The Potential of Cattails as an Energy Source. Final Report to the Minnesota Energy Agency, February 1980.

6. Andrews, N.J., M. Penko, M.D. Mattson and D.C. Pratt. 1981. The Establishment of Cattails on a Northern Minnesota Peatland. Minnesota Peat Program, Department of Natural Resources, St. Paul, MN.

7. Tisdale, S.L. and W.L. Nelson. 1975. Soil Fertility and Fertilizers. Macmillan, NY. p. 308.

8. Salisbury, F.B. and C.W. Ross. 1978. Plant Physiology, Second Edition. Wadsworth Pub. Co., Bemont, CA. pp. 82-92.

9. Andrews, N.J. et al. in preparation.

10. Gorham, E. and J.M. Bernard. 1975. Midsummer Standing Crops of Wetland Sedge Meadows Along a Transect from Forest to Prairie. J. Minn. Acad. Sci., 41 , pp. $16-17$.

11. van der Valk, A.G. and C.B. Davis. 1978. Primary Production in Prairie Glacial Marshes. In: Good, R.E. et al. (eds), Freshwater Wetlands: Production Processes and Management Potential, Academic Press, N Y.

12. Van Dyke, G.D. 1972. Aspects Relating to Emergeney Vegetation Dynamics in a Deep Marsh, Northeentral Iowa. Ph.D. Thesis, Iowa State University, Ames.

13. Klopatek, J.M. and F.W. Stearns. 1978. Primary Productivity of Emergent Macrophytes in a Wisconsin Freshwater Marsh Ecosystem. Amer. Midl. Nat., 100, pp. 320-333.

14. Murashige, T. and F. Skoog. 1962. A Revised Medium for Rapid Growth and Bioassays with Tobacco Tissue Cultures. Physiol. Plant, 15, pp. 473-497. 
15. Linsmaier, E.M. and F. Skoog. 1965. Organic Growth Factor Requirements of Tobacco Tissue Cultures. Physiol. Plant, 18, pp. 100-127.

16. Zimmerman, R.H. and O.C. Broome. 1980. Blueberry Micropropagation. In: Proceedings of the Conference on Nursery Production of Fruit Plants Through Tissue Culture - Applications and Feasibility. USDA-SEA. ARR-NE-11.

17. Economov and Read. Unpublished. 


\begin{tabular}{|c|c|c|}
\hline $\begin{array}{c}\text { Document Control } \\
\text { Page }\end{array}$ & $\begin{array}{l}\text { 1. SEAI Repor No. } \\
\text { STR-231-1819 }\end{array}$ & 3. Recipient's Accession No. \\
\hline \multirow{2}{*}{\multicolumn{2}{|c|}{$\begin{array}{l}\text { 4. Title and Subtitle } \\
\text { Emergent Aquatics: Stand Establishment, Management, } \\
\text { and Species Screening }\end{array}$}} & $\begin{array}{l}\text { 5. Publication Date } \\
\text { Nov ember } 7982 \\
\end{array}$ \\
\hline & & 6. \\
\hline $\begin{array}{l}\text { 7. Author(s) D. C. } \mathrm{Pr} \\
\text { E. G. Garver, }\end{array}$ & $\begin{array}{l}\text { tt, N. J. Andrews, D. R. Dubbe, } \\
\text { Penko, P. E. Read, E. S. Zimmerman }\end{array}$ & 8. Performing Organization Rept. No. \\
\hline \multirow{2}{*}{\multicolumn{2}{|c|}{$\begin{array}{l}\text { 9. Perorming Organization Name and Address } \\
\text { University of Minnesota } \\
\text { Bio-Energy Coordinating Office } \\
220 \text { Biological Sciences Center } \\
\text { St. Paul, Minnesota } 55108\end{array}$}} & 10. Project/Task/Work Unit No. \\
\hline & & $\begin{array}{l}\text { 11. Contract (C) or Grant (G) No. } \\
\text { (C) XK-1-1087-1 } \\
\text { (G) }\end{array}$ \\
\hline \multirow{2}{*}{\multicolumn{2}{|c|}{$\begin{array}{l}\text { 12. Sponsoring Organization Name and Address } \\
\text { Solar Energy Research Institute } \\
1617 \text { Cole Boul evard } \\
\text { Golden, Colorado } 80401\end{array}$}} & $\begin{array}{l}\text { 13. Type of Raport \& Period Covered } \\
\text { Technical Report }\end{array}$ \\
\hline & & 14. \\
\hline \multicolumn{3}{|l|}{ 15. Supplementary Notes } \\
\hline \multicolumn{3}{|c|}{$\begin{array}{l}\text { 16. Abstract (Limit: } 200 \text { words) } \\
\text { Several emergent aquatic species have been identified as potential biomass } \\
\text { crops, including Typha spp. (cattail), Scirpus spp. (rush), Sparganium spp. (bur } \\
\text { reed), and Phragmites (reed). This report discusses first year results from } \\
\text { studies of stand establishment and management, Typha nutrient requirements, wetland } \\
\text { species yield comparisons, and Typha micropropagation. } \\
\text { In a comparison of the relative effectiveness of seed, seedlings, and rhizomes } \\
\text { for stand establishment, rhizomes appeared to be more consistent and productive } \\
\text { under a wide variety of conditions. Both rhizomes and seedling established plots } \\
\text { grew successfully on excavated peatland sites. First season results from a multi- } \\
\text { year fertilizer rate experiment indicate that fertilizer treatment resulted in } \\
\text { significantly increased tissue nutrient concentrations which should carry over } \\
\text { into subsequent growing seasons. Shoot density and belowground dry weight were } \\
\text { also significantly increased by phosphorustpotassium and potassium applications, } \\
\text { respectively. First season yields of selected wetland species from managed pad- } \\
\text { dies generaliy were comparable to yields reported from natural stands. Several } \\
\text { particularly productive clones of Typha spp. have been identified. A method of } \\
\text { establishing Typha in tissue culture is described. . }\end{array}$} \\
\hline \multicolumn{3}{|c|}{$\begin{array}{l}\text { i7. Document Analysis } \\
\text { a. Descriptors Biomass plantations; Cattailis; Cultivation techniques; Land } \\
\text { reclamation; Land use; Plant growth } \\
\text { b. Identitiers/Open-Ended Terms }\end{array}$} \\
\hline \multicolumn{3}{|l|}{ c. UC Categories } \\
\hline \multicolumn{3}{|l|}{$61 a$} \\
\hline \multirow{2}{*}{\multicolumn{2}{|c|}{$\begin{array}{l}\text { 18. Availability Statement } \\
\text { National Technical Information Center } \\
\text { U.S. Department of Commerce } \\
5285 \text { Port Royal Road } \\
\text { Sorinafield Virainia } 22161\end{array}$}} & $\begin{array}{r}\text { 19. No. of Pages } \\
6\end{array}$ \\
\hline & & $\begin{array}{r}\text { 20. Price } \\
\\
\end{array} \$ 5.25$ \\
\hline
\end{tabular}

